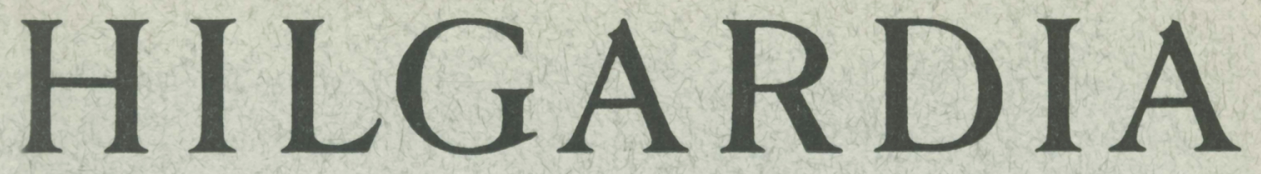

A Journal of Agricultural Science Published by the California Agricultural Experiment Station

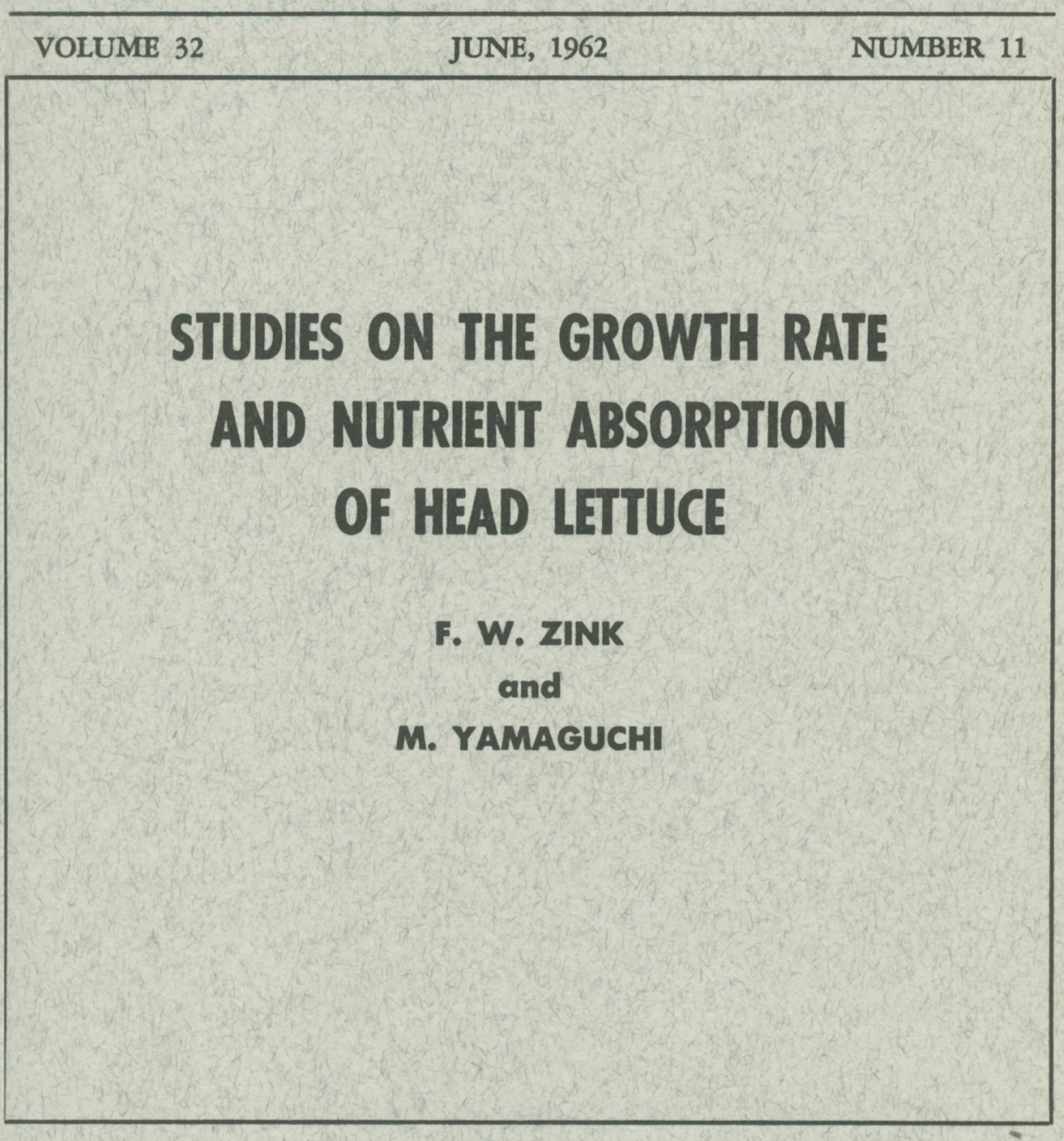

UNIVERSITY OF CALIFORNIA - BERKELEY, CALIFORNIA 


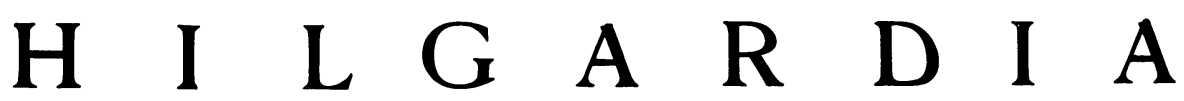

A Journal of Agricultural Science Published by

the California Agricultural Experiment Station

\section{STUDIES ON THE GROWTH RATE AND NUTRIENT ABSORPTION OF HEAD LETTUCE ${ }^{1}$}

\author{
F. W. ZINK ${ }^{2}$ and M. YAMAGUCHI ${ }^{3}$
}

\section{INTRODUCTION}

CALIForNia ranks first among the states in the commercial production of lettuce (Lactuca sativa L.), averaging slightly over 60 per cent of the national monetary value (Dean and McCorkle, 1960; Hoos and Phelps, 1948). ${ }^{4}$ Spring, summer, and fall production is concentrated in the central coastal region of the state, and the winter crop is grown in the warmer interior desert areas of the Imperial and Palo Verde valleys.

For such an important crop, only limited information is available regarding the rate of growth and course of nutrient absorption (Fujimura et al., 1960; Lorenz and Minges, 1942; McGeorge et al., 1940; Veihmeyer and Holland, 1949). A thorough knowledge of the growth pattern and nutrient uptake of lettuce is essential to a better understanding of its fertility requirements, as well as insect and disease control in the crop.

The purpose of this study was to determine the growth rate and nutrient absorption of the Great Lakes variety of lettuce during development for the spring, summer, and fall crops in the Salinas Valley of California. Although this study was restricted to the Salinas Valley, the information reported is also applicable to the Great Lakes variety when grown in other central coastal districts of California, because of the similarity in growing conditions.

\section{METHODS AND MATERIALS \\ Culture and Growth Measurements}

During 1957 and 1958, seventeen commercial fields in the Salinas Valley were selected for study. The trials were located on seven soil types that were representative of the lettuce-production area. Thermograph records were kept of the air temperatures six inches above the ground during the growing period of each of the crops.

\footnotetext{
${ }^{1}$ Received for publication November 27, 1961.

${ }^{2}$ Specialist in the Experiment Station, Department of Vegetable Crops, University of California, Davis.

${ }^{3}$ Associate Olericulturist in the Experiment Station, Department of Vegetable Crops, University of California, Davis.

${ }^{4}$ See "Literature Cited" for citations, referred to in the text by author and date.
} 
In this area, lettuce is direct-seeded as early as mid-November and as late as the second week of August, and harvesting starts in April and continues through October. Knott and Tavernetti (1944) describe the methods used to grow head lettuce in this region. The varieties planted in these trials were Great Lakes strains 118 and 366, which are very similar in growth characteristics (Zink and Welch, 1954). Irrigation, fertilizer, and cultural practices in the plots, which were each approximately two acres in area, were the same as for the commercial field in which each plot was located. These details are given in the results for each trial (trial-data tables 6-22). ${ }^{5}$

Although there is no clear-cut separation of seasonal types of lettuce, for the purpose of convenience the following classification has been established: early spring lettuce—planted during November, December, and January for harvest before May; late spring lettuce-planted during March and early April for harvest before July; summer lettuce-planted during April, May, and early June for harvest during July and August; and fall lettuceplanted in June, July, and August for harvest from September through December (Hoos and Phelps, 1948).

Lettuce plants were sampled at approximately seven-day intervals, from the time of emergence to the date of first harvest. Each sample consisted of the top portion of twenty-five to fifty plants, selected at random and cut level with the soil surface. Fifty plants were collected when the plants were small, and twenty-five plants when the crop approached market maturity. Data on fresh weight, dry weight, leaf number, and leaf area were recorded. Samples were taken before 9:00 A.M., so that the water content of the plants, as influenced by diurnal fluctuation, would be at a minimum. The samples were taken directly to the laboratory, where the fresh weight was determined, and then dried in a forced-draft oven at $140^{\circ} \mathrm{F}$. The dried material was used for mineral analysis. Data on root weight at the time of first harvest were obtained in five trials.

The number of leaves over one-sixteenth of an inch in length was counted in each head. A few of the older leaves tended to slough off as the plants approached market maturity, but a fairly accurate estimate was made by counting the leaf scars on the stem.

Leaf areas were determined on ten plants at each sampling date. The leaves from each of these plants were carefully pressed, those which were cupped in shape being cut longitudinally down the midrib and the two halves pressed. A planimeter was used to determine the leaf area.

\section{Analyses of Dry Plant Materials}

Dried plant parts were ground in a Wiley mill to pass a twenty-mesh screen. A representative sample of this material was used for analysis of the following constituents:

Nitrate-Nitrogen. The weighed ground sample was extracted overnight with 2 per cent acetic acid. A little charcoal (Norit A) was added to clear the solution before filtering. Nitrate-nitrogen was then determined by the conventional phenoldisulfonic acid method.

${ }^{5}$ All the tables in this paper are grouped following the last page of text starting on page 486. Seventeen interrelated tables ( 6 through 22 ), giving the results of a series of trials, start on page 488, under the heading "Trial Data-1957-1958." 
Total Nitrogen and Phosphorus. These were determined by standard procedures given by the A.O.A.C. (Horowitz, 1955).

Potassium, Sodium, Calcium, and Magnesium. The concentration of each of these elements was obtained by analysis of the ashed sample, utilizing a flame spectrophotometer (Yamaguchi and Minges, 1956).

In the text, tables, and figures, the elemental symbols $\mathrm{N}, \mathrm{P}, \mathrm{K}, \mathrm{Na}, \mathrm{Ca}$, and $\mathrm{Mg}$ are used for compositional content, expressed on a dry-weight basis, in the plant tissues. The symbols $\mathrm{N}, \mathrm{P}_{2} \mathrm{O}_{5}$, and $\mathrm{K}_{2} \mathrm{O}$ are used to express amounts of nutrients, expressed in pounds per acre, applied or removed.

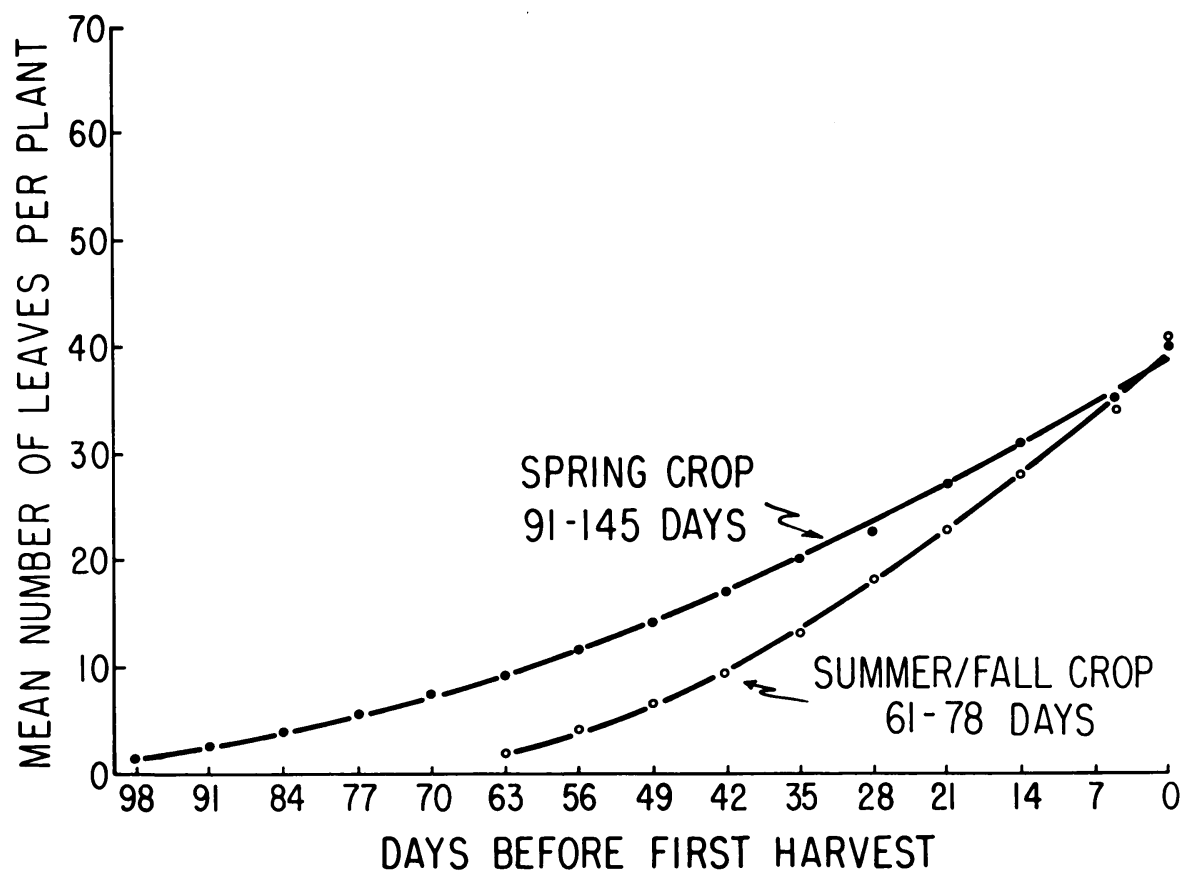

Fig. 1. Comparison of mean number of leaves per plant during growth of spring lettuce crops with that of summer or fall crops.

\section{RESULTS AND DISCUSSION \\ Plant Growth Characteristics}

The leaves of lettuce plants are alternate and arise from a short stem. The outermost leaves of the rosette are large and spreading and are termed "frame leaves." The few intermediate leaves that fold loosely over the head are called "wrapper leaves." The inner leaves are interlapped to form the firm terminal bud that is commonly called the "head." The leaves forming the terminal bud are called "head leaves," and the outermost leaf that covers the head is termed the "cap leaf."

Leaf Number. The number of leaves per plant, plotted against days before first harvest, is shown in figure 1. The trials were arbitrarily separated into groups based on time to maturity-those requiring 91 to 145 days and those 
requiring 61 to 78 days from planting to first harvest. The early and late spring crops, with the exception of trial 58-5 (table 19), belong to the former group; the summer and fall crops, to the latter group. In both groups, the number of leaves increased fairly uniformly, but with a slightly increased rate as the plants approached market maturity.

The total leaf number in market-mature lettuce plants ranged from 39 to

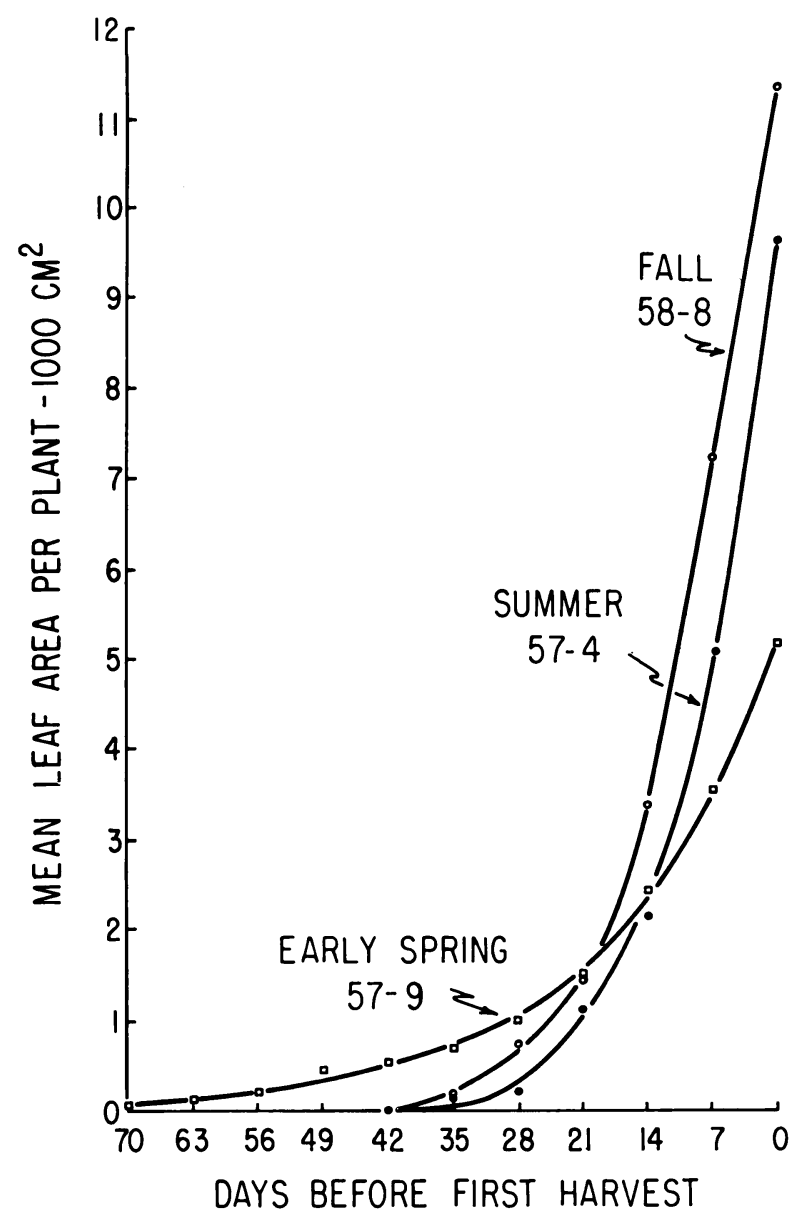

Fig. 2. Increase in mean leaf area per plant during growth for early spring, summer, and fall lettuce crops. The references are to tables 22,9 , and 14 , in that order.

47 per plant, and the number of frame and wrapper leaves, from 14 to 20 . The basis for determining market maturity was head firmness. Plants that reached first harvest in 91 to 145 days showed the first head leaf (cap leaf) approximately 42 to 49 days before first harvest. In the lettuce that matured in 61 to 78 days, the first head leaf was visible approximately 28 to 35 days before harvest. However, the actual head development for both groups did not start until about 21 days before first harvest. 
Leaf Area. The mean leaf area per plant at various stages of growth is shown in figure 2 for three trials. The increase in leaf area per plant was quite slow during the early period of growth. Following this, the growth curve followed the characteristic shape representing the grand period of growth. Since the increase in leaves per plant was fairly constant during this period, the rapid increase in leaf area was the result of an accelerated increase in the area per leaf.

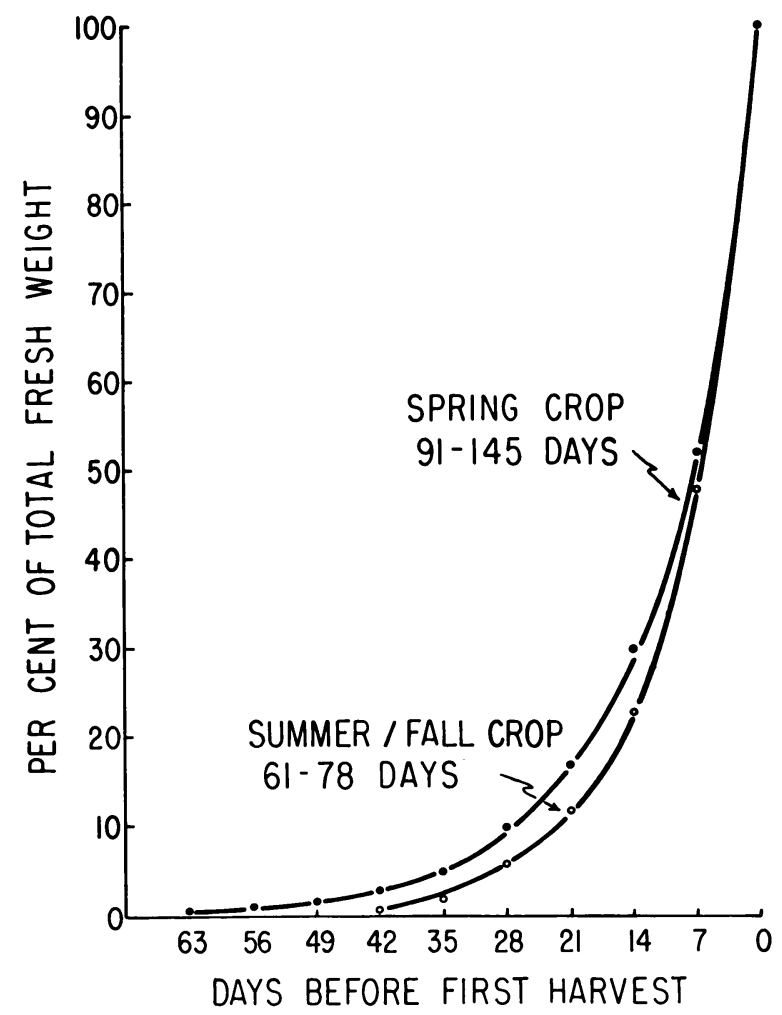

Fig. 3. Growth, expressed as per cent of total fresh weight per plant, for spring and summer or fall lettuce.

The growth curve for leaf area was not so steep during the grand growth period for crops maturing in the early spring as that found for late spring, summer, and fall crops. For example, trial 57-9, a 128-day early spring crop, developed 65.4 per cent of its leaf area in the 21-day period before first harvest, while trial 58-8, a 70-day fall crop, developed 83.4 per cent of its leaf area in the same length of time (tables 14 and 22).

A comparison of the area of the frame and wrapper leaves with that of the head leaves at the time of first harvest showed that the frame and wrapper leaves comprised from 49 to 65 per cent of the total leaf area per plant. The mean leaf area per plant at the time of first harvest was found to range from 4,760 to 11,400 square centimeters, or 5.1 to 12.3 square feet. 
Fresh and Dry Weights of Plant. Another index of plant growth is the plant weight. The growth of lettuce, expressed as per cent of the total fresh weight at harvest, is shown in figure 3. Plants reaching first harvest in 91 to 145 days were found to produce in excess of 70 per cent of their ultimate fresh weight in the 21 days before first harvest, and from 36 to 65 per cent in the week immediately preceding it. Plants in the group requiring 61 to 78 days to maturity produced in excess of 80 per cent of the fresh weight in the 21 days before first harvest, and 43 to 57 per cent in the week immediately preceding first harvest. In general, the growth curve was less steep in the crops that required a longer period to reach market maturity.

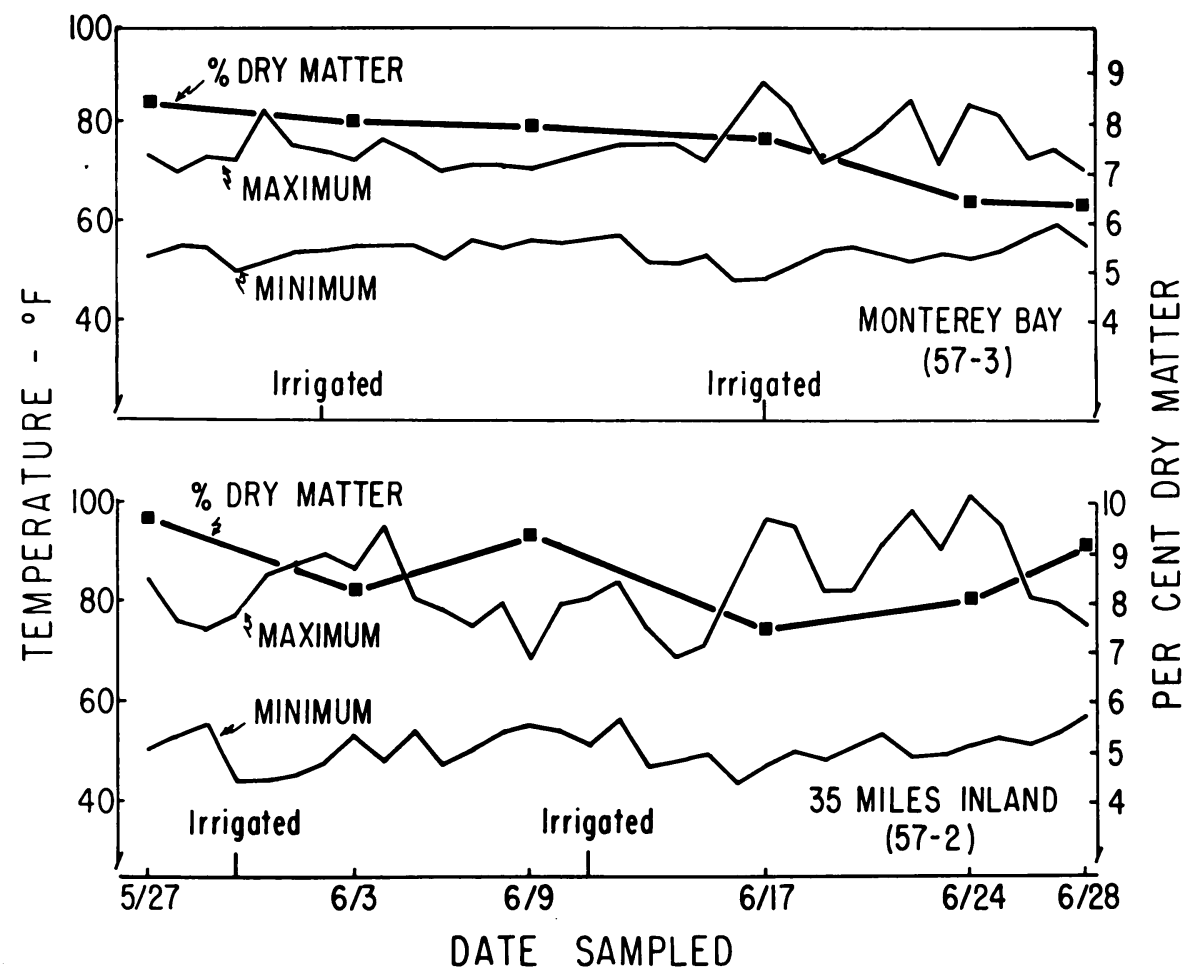

Fig. 4. Comparison of per cent of dry matter of lettuce grown in the same season but at different locations and under different climatic conditions.

McGeorge et al. (1940) and Lorenz and Minges (1942) reported that the per cent of dry matter in lettuce plants decreased as the plants approached market maturity. A similar trend was observed in most of the trials reported in this study. However, in four of the seventeen trials, the per cent of dry matter increased the last four to seven days before first harvest. The per cent of dry matter appears to be influenced by the climatic conditions and/or the irrigation schedule. For example, trials 57-3 and 57-2 (tables 8 and 7), grown during the same period in different locations and microclimates, demonstrated this phenomenon (fig. 4). Trial 57-3, grown close to Monterey Bay under moderate temperature and wind velocity, decreased in per cent 
of dry matter as the plants approached market maturity. The per cent of dry matter at first harvest was 6.3. Trial 57-2, grown some thirty-five miles from the bay under increased temperature and wind velocity, and with no irrigation during the eighteen days before first harvest, increased in dry matter the last twelve days to 9.1 per cent. In this trial the plants showed temporary wilting the last three days before harvest, indicating water stress.

Temperature Effects on Growth. Climate in the Salinas Valley is influenced by proximity to the surrounding hills and to the sea. Hence, there are a number of microclimates within the lettuce-producing areas of the valley.

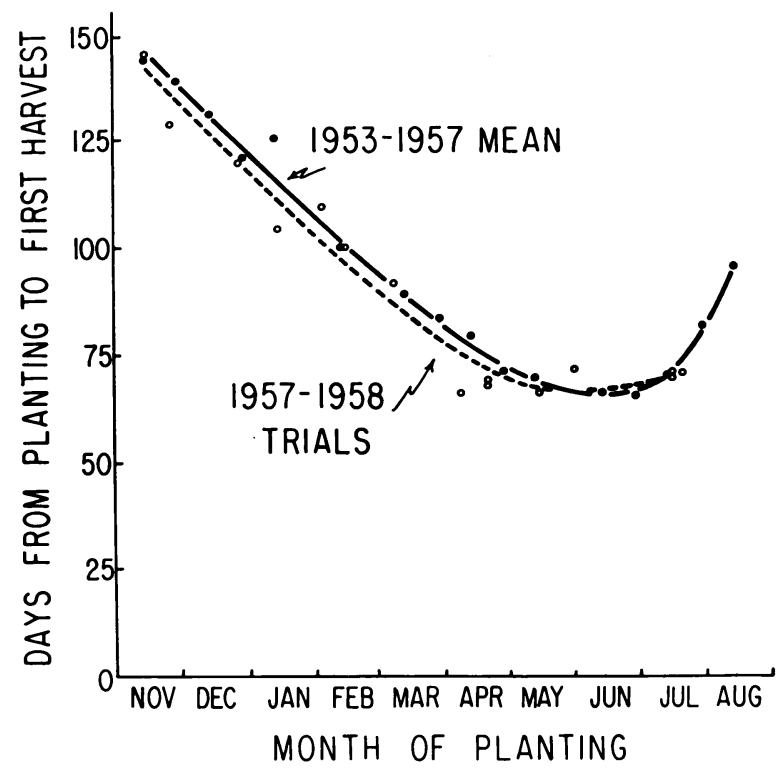

Fig. 5. Days required from seeding to first harvest for 312 crops of Great Lakes lettuce in the Salinas Valley, 1953-1957 (mean days), and for trials in 1957-1958.

The possibility of using temperature summation methods was explored to determine if the heat-sum concept could account for the time required for lettuce to reach market maturity. The remainder-index system was used for accumulating temperatures. A daily mean was established by averaging daily maximums and minimums. The difference between this mean and the $40^{\circ} \mathrm{F}$. base was accumulated daily for each trial from planting to first harvest. This summation of remainder indices has been designated as "growing degree days."

Selection of a base temperature of $40^{\circ} \mathrm{F}$. for the calculation of remainder indices was made after a study of the data, using base temperatures of 50 , 45,40 , and $35^{\circ} \mathrm{F}$. It was found that the lower the base used, the smaller was the coefficient of variation of the means. Since lettuce plants grow slowly when the mean temperature is below $45^{\circ}$, a base of $40^{\circ} \mathrm{F}$. seemed the lowest that was physiologically justified. The data reported in table 1 indicate that Great Lakes lettuce does not utilize the same amount of heat to reach market maturity when planted at different times of the year or in different micro- 
climates on the same date. These results are in agreement with the lettuce temperature summation study of Madariaga and Knott (1951).

The mean number of days from planting to first harvest for seedings made in any given month in the Salinas Valley is shown in figure 5 for 312 Great Lakes crops grown in the years 1953 to 1957, inclusive. These data were collected from growers' records. A close similarity between this average and that of our 1957 and 1958 trials is apparent.

\section{Nutrient Absorption and Mineral Content During Growth}

The objective of lettuce growers is the production of marketable, crisp, firm, green heads, free of seedstalks and disease. A knowledge of the nutrient requirements of the plant during growth would be of great importance in planning a fertilizing program to obtain quality production with minimum costs. Trial-data tables 6-22 show for each trial the fertilizer program and the mineral contents of the lettuce plants during growth.

Total Nitrogen. The amount of nitrogen applied varied from a low of 121 pounds per acre to a high of 300 pounds per acre. Total nitrogen, expressed as per cent of dry weight, fluctuated somewhat throughout the growth of the plant, with a trend in all trials to decrease as the plant approached market maturity. The range in total nitrogen was from 6.65 to 3.10 per cent. No relation was noted between the total nitrogen content of the aboveground portion of the plant at first harvest and the amount of nitrogen applied to the crop.

Nitrate-Nitrogen. Nitrate-nitrogen $\left(\mathrm{NO}_{3}-\mathrm{N}\right)$ fluctuated during the growth period. These fluctuations, for the most part, were related to the rate of growth and/or time of nitrogen fertilization. A general pattern of nitratenitrogen content in the aboveground portion of the plant was observed. During the early phase of growth, there was a decrease in nitrate-nitrogen. Following thinning and a sidedressing of nitrogen, the nitrate-nitrogen content of the plant increased sharply and then tended to level off. A second application of nitrogen during the last twenty-eight days of growth increased the nitrate-nitrogen level or maintained it. This relationship of nitratenitrogen content in the plant to the time of nitrogen fertilization is shown graphically in figure 6 for trial 57-7 (table 12). In contrast, trial 57-3 (table 8 ), illustrated in figure 7 , which had only one sidedressing of nitrogen shortly after thinning, showed a sharp increase in nitrate-nitrogen and then a rapid decrease during the eleven days before first harvest.

It has been determined from fertilizer experiments that about 0.50 per cent nitrate-nitrogen in the midrib tissue is sufficient for maximum production (Lorenz et al., 1956). Since the nitrate-nitrogen concentration in midrib tissue is approximately two times that in the entire aboveground portion of the plant, nitrate-nitrogen levels below 0.25 per cent of dry weight in the aboveground portion of the plant were considered critical. Most samples were above this critical level. Trials 57-4, 57-9, 58-1, 58-2, and 58-5 (tables 9, 14, 15, 16, and 19) fell below the critical nitrate-nitrogen level during the early phase of growth (shortly after thinning), but this condition was corrected by subsequent nitrogen fertilization. Trial 57-3 (table 8) was the only crop below the critical level on the date of first harvest. 
No relationship was found between the nitrate-nitrogen content of the aboveground portion of the plant and the amount of nitrogen applied. This was probably due to the fact that the nitrate-nitrogen content of the plant was largely dependent upon the time of application of nitrogen fertilizer and on the growth rate of the plant.

Lorenz et al. (1956) reported a significant and high correlation coefficient between total nitrogen and acetic acid-soluble nitrate-nitrogen in the midrib tissue of wrapper leaves. No such correlation between total nitrogen and

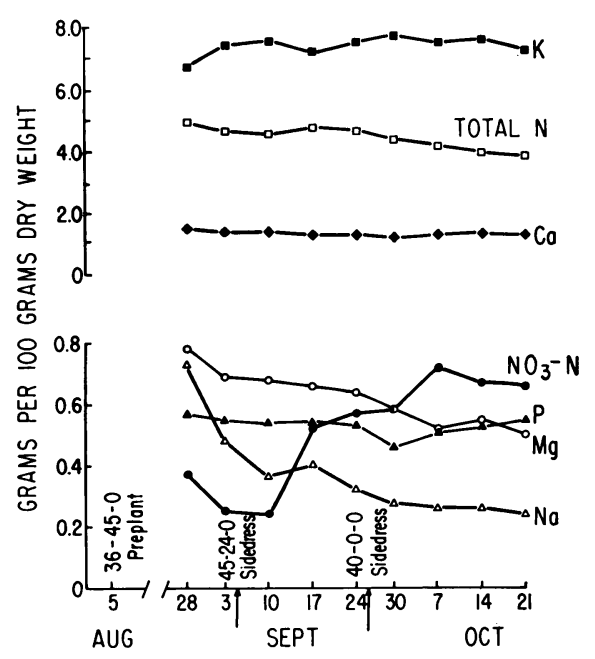

Fig. 6. Mineral content of the aboveground portion of the plants during the growth of trial 57-7 (table 12). Fertilizer rates are expressed as pounds of $\mathrm{N}, \mathrm{P}_{2} \mathrm{O}_{5}$, and $\mathrm{K}_{2} \mathrm{O}$ per acre; arrows indicate dates sidedressed.

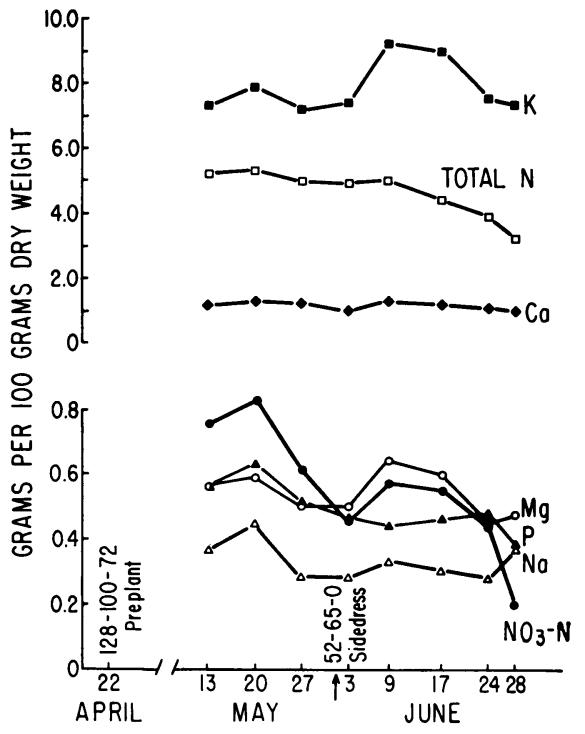

Fig. 7. Mineral content of the aboveground portion of the plants during the growth of trial 57-3 (table 8). Fertilizer rates are expressed as pounds of $\mathrm{N}, \mathrm{P}_{2} \mathrm{O}_{5}$, and $\mathrm{K}_{2} \mathrm{O}$ per acre; arrow indicates date sidedressed.

nitrate nitrogen was found in this study when the entire aboveground portion of the plant was analyzed.

Phosphorus. The amount of $\mathrm{P}_{2} \mathrm{O}_{5}$ applied to these trials varied from 0 to 180 pounds per acre. The phosphorus content of the plant fluctuated somewhat throughout the growth of any given trial. A tendency for the phosphorus content to decrease as the plants approached market maturity was observed in most of the trials. The fluctuations in the phosphorus content could not be correlated with phosphorus fertilization during the growth of the crop. Phosphorus content of the aboveground portion of the plant ranged from a high of 0.79 to a low of 0.34 per cent of dry weight. The majority of the samples were in the range of 0.60 to 0.40 per cent. The data showed that all the samples analyzed higher in phosphorus than the 0.20 per cent which had been suggested as a critical level (Lorenz et al., 1956).

No relationship was found between the amount of phosphorus applied to 
the soil and the amount of phosphorus found in the aboveground portion of the plant at harvest.

Potassium. The amount of potassium applied to the crop varied from 0 to a high of 100 pounds of $\mathrm{K}_{2} \mathrm{O}$ per acre. The potassium content fluctuated; no general trend was observed. The range in potassium content was from a high of 9.44 to a low of 4.57 per cent. All samples were much higher in potassium content than is considered to be necessary for maximum growth (Lorenz et al., 1956).

No relationship was found between the amount of potassium applied and the amount found in the aboveground portion of the plant.

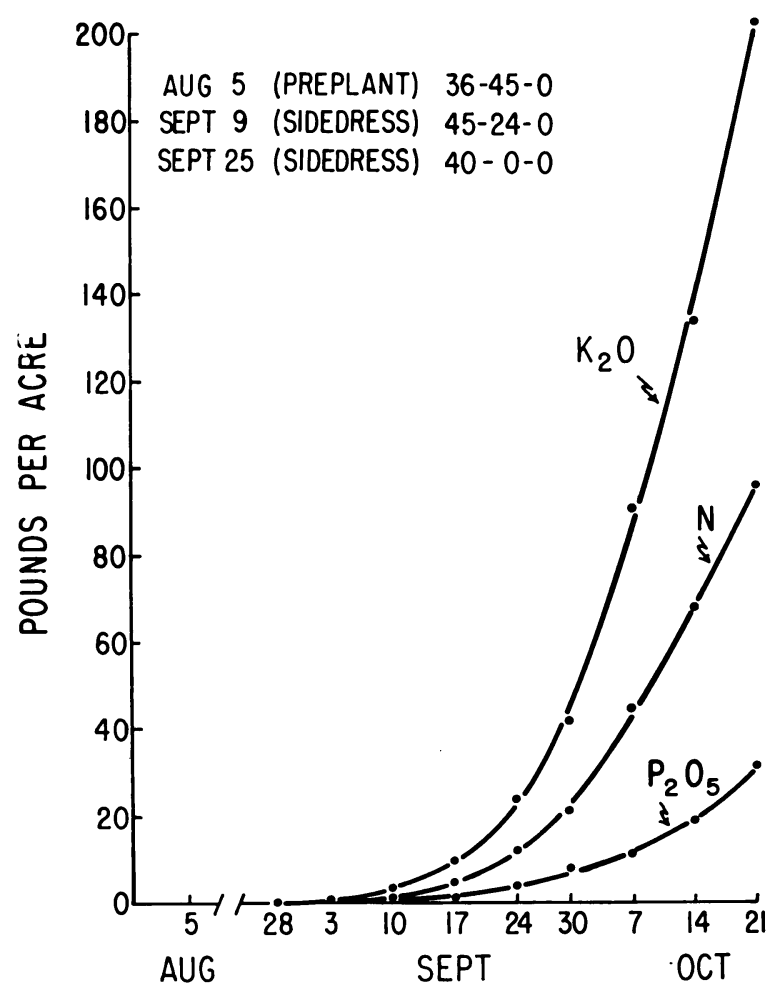

Fig. 8. Mineral absorption of the aboveground portion of the plants during the growth of trial 57-7 (table 12). Fertilizer rates are expressed as pounds of $\mathrm{N}, \mathrm{P}_{2} \mathrm{O}_{5}$, and $\mathrm{K}_{2} \mathrm{O}$ per acre; dates of application are shown.

Calcium. The calcium content of the aboveground portion of the plant remained fairly constant throughout the growth of any given crop. The range in calcium content found in these studies was from a high of 1.60 to a low of 0.91 per cent.

Magnesium. The magnesium content of the aboveground portion of the plant fluctuated slightly throughout the growth of the crop, but tended to decrease as the plants approached market maturity. The range in magnesium was from a high of 0.84 to a low of 0.32 per cent. 
Sodium. The sodium content of the aboveground portion of the plant fluctuated during earlier growth, but in most trials tended to decrease as the plants approached market maturity.

Comparison of Roots and Tops. Comparisons were made of root and top samples taken at the date of first harvest. Table 2 shows the mineral content of the aboveground portion and of the roots. A comparison of the analyses

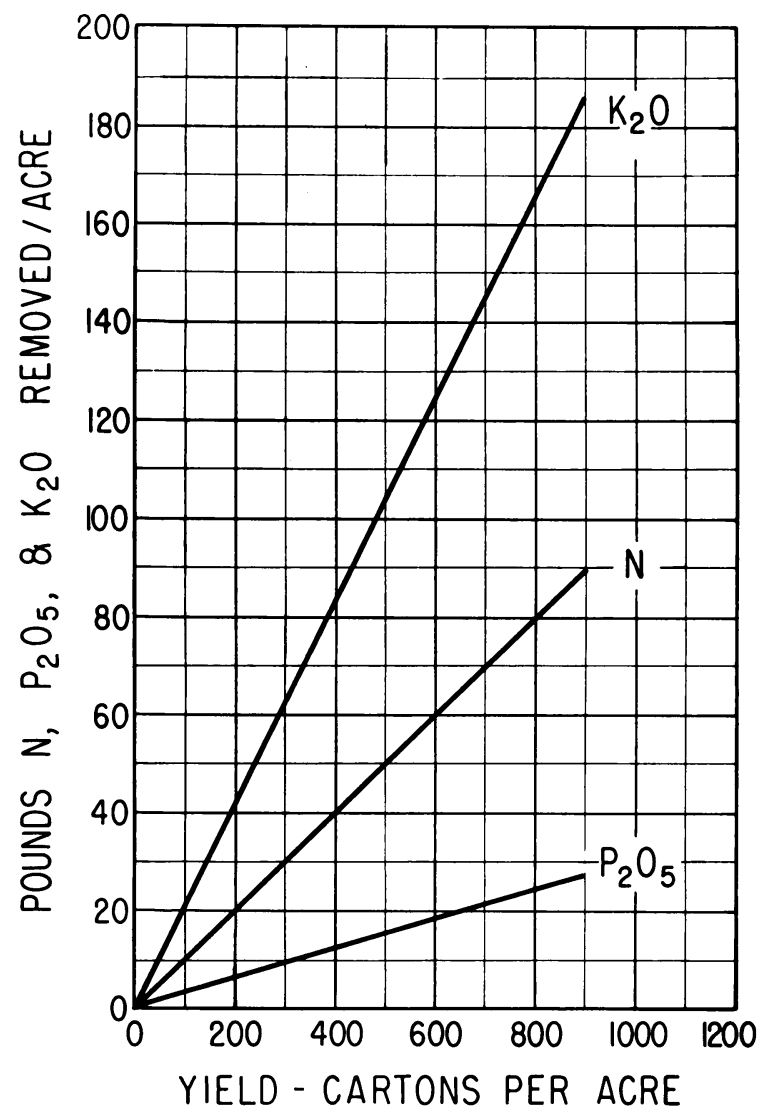

Fig. 9. Pounds per acre of nitrogen, phosphoric acid, and potash removed at different yield levels. Calculated on the basis of forty-five pounds of fresh-weight lettuce per carton at 6 per cent dry matter, and mineral content for $\mathrm{N}=3.7, \mathrm{P}=0.5$, and $\mathrm{K}=6.4$ expressed as per cent of dry weight.

of these two parts of the plant shows significant differences. Nitrate-nitrogen was higher in the tops than in the roots, with the exception of trial 58-2, in which the roots were slightly higher in content. Total nitrogen and phosphorus contents in the tops and roots were approximately the same. Potassium, calcium, and magnesium were higher in the tops than in the roots. Sodium was higher in the roots than in the tops.

Nutrient Uptake Curves. The nutrient removal from the soil by the crop was calculated from the plant analyses and growth rates. Based on an average of 22,200 plants per acre, figure 8 shows the cumulative nitrogen, phosphorus, 
and potassium uptake for the aboveground portion of a typical lettuce crop. The shape of the nitrogen, phosphorus, and potassium uptake curves was very similar to that of dry-matter production. The rate of nutrient removal was very slow during the early phase of growth. Approximately one week after thinning, each of the seventeen crops studied had removed less than 2.5 pounds of nitrogen, 1 pound of phosphoric acid $\left(\mathrm{P}_{2} \mathrm{O}_{5}\right)$, and 4 pounds of potash $\left(\mathrm{K}_{2} \mathrm{O}\right)$ per acre. Maximum rate of growth during the twenty-one days before first harvest was accompanied by the maximum rate of nitrogen, phosphorus, and potassium uptake. During this period, in excess of 70 per cent of the nitrogen, phosphorus, and potassium was removed. Similarly shaped nutrient removal curves were found for calcium, magnesium, and sodium.

Pounds of nitrogen, phosphoric acid, and potash applied to the seventeen crops and calculated pounds removed by the aboveground portion of the plants at the time of first harvest are presented in table 3. Trials 57-8 and 57-9 were relatively low in nutrients removed. This was the result of small head size rather than low mineral content in the plants.

Calculated pounds per acre of sodium, calcium, and magnesium removed by the aboveground portion of the plants are presented in table 4. Calcium absorbed by any given crop in these studies was equal to or slightly higher than the intake of $\mathrm{P}_{2} \mathrm{O}_{5}$. Magnesium removed by the aboveground portion of the plants varied from a high of 15.6 to a low of 5.2 pounds per acre, while sodium varied from a high of 15.9 to a low of 4.1 pounds.

The calculated pounds of minerals in the root system of an acre of lettuce at first harvest are shown in table 5. These were relatively low when compared to the tops. Less than 5 per cent of the nitrogen and potassium and less than 6 per cent of the phosphorus absorbed by the crops were in the root system of the plants on the date of first harvest.

Figure 9 shows the pounds of nitrogen, phosphoric acid, and potash removed from an acre at various yield levels. Calculations were made from the average mineral content of the aboveground portion of the plants from all trials at first harvest. Such information could be useful in determining the residual fertilizer from a lettuce crop. It is recognized that the cutout yield, or the actual plants harvested, will be far less than the average 22,200 lettuce plants per acre. The actual pounds of nutrients removed from an acre depend primarily on the yield and level of minerals in the harvested portion.

\section{GENERAL DISCUSSION AND CONCLUSIONS}

The data reported in this study follow the development of the plant during the grand period of growth. All trials were terminated on the date of first harvest of the crop, and no information was obtained on the reproductive phase of growth.

The data presented on the quantitative expression of lettuce growth suggest a number of practical factors to be considered by those associated with the lettuce industry. The rapid increase in leaf area during the growth of the crop indicates that only a relatively short period of protection may be expected from a foliar fungicide, regardless of its residual strength. Consideration needs to be given to the amount of leaf surface area in an acre of 
lettuce at various stages of growth in determining the quantity of an agricultural chemical to be applied in order to assure thorough coverage. Application of the same volume per acre throughout the growth of the crop would indicate either excessive amounts when the plants were small or inadequate coverage when the plants were larger. The accelerated rate of increase in fresh and dry weight per plant during the grand growth period suggests that there would be a rapid dilution of a systemic insecticide and/or fungicide, and that its period of effectiveness would thereby be reduced.

Plants in this study produced in excess of 70 per cent of their fresh weight in the twenty-one days immediately preceding first harvest. Symptoms of some factor or factors capable of limiting growth during this phase of plant development would indicate a reduction in yield. Careful manipulation of cultural practices is necessary to assure optimum conditions for growth during this period. Such practices would include maintaining adequate soil moisture, soil fertility, and soil structure and providing protection against injury due to insects and disease. Zink and Kimble (1960) have shown the relationship of the stage of plant development at the time of infection with lettuce mosaic virus to the resultant rate of growth and yield.

The temperature and growth data suggest that the Great Lakes variety can produce satisfactory heads with a mean air temperature during the twenty-one-day period before first harvest in the range of 51 to $67^{\circ} \mathrm{F}$. Great Lakes has a relatively broader temperature adaptation range than the Imperial varieties, and is widely adapted to culture under different sets of environmental conditions (Bohn and Whitaker, 1951).

Went (1950) has shown that the relationship between temperature and growth is not a direct one throughout the range at which plants grow. From bases of $35,40,45$, or $50^{\circ} \mathrm{F}$., heat-sum units cannot account for the number of days from planting to market-mature lettuce. There are a number of known factors that may interact with temperature in determining the rate of maturity of head lettuce. McGeorge et al. (1940) demonstrated that highphosphate fertilizer application increased maturity and nitrogen delayed it. Zink and Grogan (1954) reported that the "big vein" disease of lettuce retards market maturity, and Zink and Kimble (1960) reported that early infection by lettuce mosaic hastens maturity.

It has long been recognized that lettuce grown in California gives large increases in yield when adequately supplied with commercial fertilizer, particularly nitrogen. Results of some early fertilizer experiments on lettuce show that 47 pounds of nitrogen, 16 pounds of phosphoric acid $\left(\mathrm{P}_{2} \mathrm{O}_{5}\right)$, and 117 pounds of potash $\left(\mathrm{K}_{2} \mathrm{O}\right)$ were absorbed per acre in the growth of the crop (Lorenz and Minges, 1942). McGeorge et al. (1940) reported 50 pounds of nitrogen and 21 pounds of phosphoric acid $\left(\mathrm{P}_{2} \mathrm{O}_{5}\right)$ absorbed by a lettuce crop in Arizona. Since these reports, commercial plantings have changed from the Imperial types to predominantly Great Lakes strains. This variety, grown as a spring, summer, and fall crop, produces a larger head than the Imperial types, which accounts in part for the generally higher nutrient absorption data reported in the present study. The nutrient absorption data for trials 57-8 and 57-9 (tables 13 and 14), which are in agreement with the early reports, should not be considered typical of Great Lakes, since in these two 
trials plant size was small. If trials 57-8 and 57-9 are not considered, the average nutrient absorption for 15 crops would be 95 pounds of nitrogen, 27 pounds of phosphoric acid $\left(\mathrm{P}_{2} \mathrm{O}_{5}\right), 208$ pounds of potash $\left(\mathrm{K}_{2} \mathrm{O}\right), 9$ pounds of sodium, 33 pounds of calcium, and 12 pounds of magnesium per acre. These figures are perhaps a little on the low side, since the study was terminated at first harvest and some of the plants had not reached market maturity. However, they do establish to a degree the nutrient absorption of Great Lakes lettuce.

A re-evaluation of current fertilizer practices would seem to be logical in the light of the information on nutrient uptake and growth pattern reported here. The practice of applying as a preplant one-half to two-thirds the total amount of nitrogen expected to be used to grow the crop is questionable. Nitrogen is mobile and may be lost as nitrate either by leaching or as surface saline accumulation in the center surface of the bed. Since lettuce absorbs little nitrogen in the early phase of growth, a more realistic program would be a preplant with one-fourth the amount of nitrogen expected to be used to grow the crop; the remaining nitrogen would then be applied as two sidedressings - one after thinning, and a second approximately a month before the predicted first harvest. Such a program would assure an ample supply of nitrogen in the root zone during the period of maximum absorption.

Phosphorus fertilizer should be applied preplant to get the maximum benefit from its use. Sidedressing additional phosphorus fertilizer during the growth of the crop had no apparent effect on the phosphorus content of the plants in this study.

Plant analyses in this study and in a lettuce nutrient survey in the Salinas Valley in 1954 (Lorenz et al., 1956) indicate that the potassium content of plants grown with no potash fertilizer was much higher than is considered necessary for optimum growth. This indicates that for the present, the soils in the Salinas Valley have a supply of potassium ample to meet the requirements of the crop. The fertilizer program must be evaluated on the basis of residual fertilizer in the soil, nutrient requirements, nutrient uptake curve, and growth pattern of the crop.

\section{SUMMARY}

1. Great Lakes lettuce developed new leaves at a nearly constant rate from emergence to market maturity.

2. Leaf area per plant increased at a progressively accelerated rate. The rapid increase in leaf area per plant was the result of an accelerated rate of increase in area per leaf, and was not due to rapid increase in leaf number per plant.

3. Correlated with the increase in leaf area was a progressive acceleration in the rate of increase in fresh and dry weight per plant. In these trials, Great Lakes produced in excess of 70 per cent of its fresh weight during the twenty-one-day period preceding first harvest, and in excess of 36 per cent of its fresh weight the week before first harvest.

4. In general, the per cent of dry matter decreased as the plant approached market maturity. The fluctuation in dry matter during the growth of some crops was correlated with climatic conditions and/or the irrigation schedule. 
5. The Great Lakes variety did not utilize the same amount of heat units to reach market maturity when planted at different times of the year or in different microclimates on the same date. Lettuce of good quality was produced with a mean temperature in the range of 51 to $67^{\circ} \mathrm{F}$. during the headformation period of growth.

6. Chemical analyses of the plants showed a trend for total nitrogen, phosphorus, magnesium, and sodium to decrease as the plants approached market maturity. The calcium level of the plants remained at a near constant throughout the growth of the crops. The potassium content fluctuated, and no general trend was observed. Nitrate-nitrogen fluctuated throughout the growth of the crops. These fluctuations in nitrate-nitrogen can be related to nitrogen fertilizer application and/or rate of growth.

7. The shape of the nitrogen, phosphorus, potassium, calcium, magnesium, and sodium uptake curves was very similar to that for dry-matter production. Over 70 per cent of the nutrient uptake of the crop was absorbed during the twenty-one days immediately preceding first harvest.

8. From the time of planting to a week after thinning, lettuce absorbed less than 2.5 pounds of nitrogen, 1 pound of phosphoric acid, and 4 pounds of potash per acre. By first harvest, the crop had removed an average of 95 pounds of nitrogen, 27 pounds of phosphoric acid, 208 pounds of potash, 9 pounds of sodium, 33 pounds of calcium, and 12 pounds of magnesium per acre.

\section{ACKNOWLEDGMENTS}

The authors wish to thank Professor J. E. Knott for many helpful suggestions and for his review of the manuscript, Messrs. J. W. Perdue and P. J. Riddle for assistance in the chemical analyses, and Mrs. S. S. Stein for drafting the figures. 


\section{TABLES}

TABLE 1

PLANTING DATES, DAYS TO FIRST HARVEST, AND SUMMATION OF GROWING DEGREE DAYS $\left(40^{\circ}\right.$ F. BASE) FOR LETTUCE GROWTH STUDY, 1957-1958

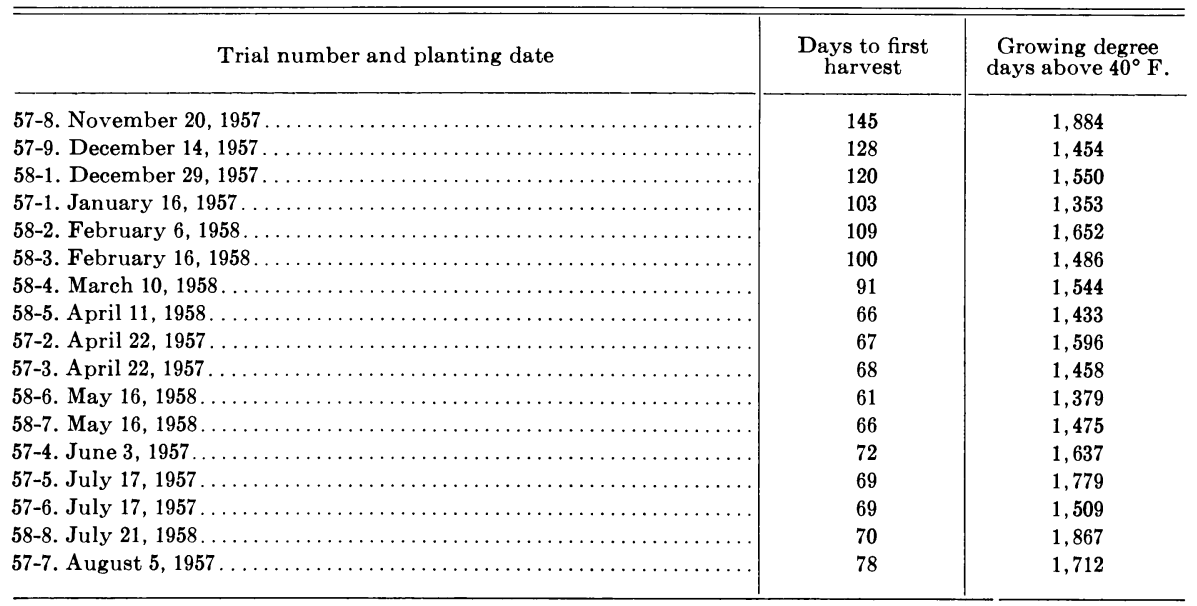

TABLE 2

COMPARISON OF THE MINERAL CONTENT OF THE ABOVEGROUND PORTION OF THE PLANTS WITH THAT OF THE ROOTS

ON DATE OF FIRST HARVEST

\begin{tabular}{|c|c|c|c|c|c|c|c|c|}
\hline \multirow{2}{*}{ Trial no. } & \multirow{2}{*}{$\begin{array}{c}\text { Plant } \\
\text { portion } \\
\text { analyzed }\end{array}$} & \multicolumn{7}{|c|}{ Per cent of dry weight } \\
\hline & & $\mathrm{NO}_{3}-\mathrm{N}$ & $\mathrm{N}$ & $P$ & $\mathbf{K}$ & $\mathrm{Na}$ & $\mathrm{Ca}$ & $\mathbf{M g}$ \\
\hline \multirow[t]{2}{*}{$57-9 \ldots \ldots \ldots$} & Top & 0.50 & 3.59 & 0.54 & 5.25 & 0.30 & 1.24 & 0.43 \\
\hline & Root & 0.39 & 2.22 & 0.58 & 4.46 & 0.43 & 0.46 & 0.17 \\
\hline \multirow[t]{2}{*}{$58-2 \ldots \ldots \ldots$} & Top & 0.48 & 3.73 & 0.49 & 7.35 & 0.49 & 1.35 & 0.48 \\
\hline & Root & 0.53 & 2.52 & 0.49 & 6.11 & 0.73 & 0.55 & 0.27 \\
\hline \multirow[t]{2}{*}{ 58-3. } & Top & 0.42 & 3.64 & 0.43 & 6.77 & 0.24 & 1.50 & 0.51 \\
\hline & Root & 0.24 & 1.95 & 0.45 & 4.89 & 0.49 & 0.65 & 0.21 \\
\hline \multirow[t]{2}{*}{$58-4 \ldots$} & Top & 0.40 & 3.10 & 0.39 & 6.11 & 0.25 & 1.29 & 0.42 \\
\hline & Root & 0.35 & 1.86 & 0.39 & 5.09 & 0.57 & 0.71 & 0.18 \\
\hline \multirow[t]{2}{*}{$58-6 .}$. & Top & 0.56 & 3.85 & 0.49 & 5.90 & 0.41 & 1.44 & 0.43 \\
\hline & Root & 0.38 & 2.00 & 0.43 & 4.78 & 0.75 & 0.69 & 0.20 \\
\hline
\end{tabular}


TABLE 3

POUNDS PER ACRE OF MINERALS APPLIED AS FERTILIZER, AND CALCULATED AMOUNT REMOVED BY THE ABOVEGROUND PORTION OF THE PLANTS ON DATE OF FIRST HARVEST

\begin{tabular}{|c|c|c|c|c|c|c|}
\hline \multirow{2}{*}{ Trial no. } & \multicolumn{2}{|c|}{$\begin{array}{c}\mathrm{N} \\
\text { Pounds per acre }\end{array}$} & \multicolumn{2}{|c|}{$\begin{array}{c}\mathrm{P}_{2} \mathrm{O}_{5} \\
\text { Pounds per acre }\end{array}$} & \multicolumn{2}{|c|}{$\begin{array}{c}\mathrm{K}_{2} \mathrm{O} \\
\text { Pounds per acre }\end{array}$} \\
\hline & Applied & Removed & Applied & Removed & Applied & Removed \\
\hline $57-1 \ldots \ldots \ldots \ldots$ & 178 & 95.5 & 108 & 28.3 & 0 & 190.7 \\
\hline $57-2 \ldots \ldots \ldots \ldots \ldots \ldots \ldots$ & 126 & 119.8 & 93 & 31.9 & 0 & 266.5 \\
\hline $57-3 \ldots \ldots \ldots \ldots \ldots \ldots$ & 180 & 78.4 & 165 & 21.9 & 72 & 215.8 \\
\hline $57-4 \ldots \ldots \ldots \ldots \ldots \ldots$ & 156 & 103.2 & 115 & 32.1 & 36 & 225.0 \\
\hline $57-5 \ldots \ldots \ldots \ldots \ldots \ldots$ & 140 & 103.3 & 0 & 30.5 & 0 & 237.5 \\
\hline $57-6 \ldots \ldots \ldots \ldots \ldots \ldots$ & 300 & 73.5 & 180 & 22.8 & 72 & 160.9 \\
\hline $57-7 \ldots \ldots \ldots \ldots \ldots \ldots$ & 121 & 96.4 & 69 & 31.8 & 0 & 214.1 \\
\hline $57-8 \ldots \ldots \ldots \ldots \ldots$ & 145 & 50.5 & 64 & 16.2 & 20 & 75.9 \\
\hline $57-9 \ldots \ldots \ldots$ & 236 & 55.8 & 75 & 19.2 & 54 & 98.2 \\
\hline $58-1 \ldots \ldots \ldots$ & 163 & 95.9 & 0 & 21.9 & 0 & 122.2 \\
\hline $58-2 \ldots$ & 216 & 121.3 & 75 & 37.1 & 54 & 287.8 \\
\hline $58-3 \ldots$ & 153 & 92.6 & 116 & 24.8 & 0 & 207.4 \\
\hline $58-4$ & 153 & 74.9 & 116 & 21.8 & 0 & 177.8 \\
\hline $58-5 \ldots$ & 153 & 89.1 & 116 & 25.6 & 0 & 194.9 \\
\hline $58-6 \ldots$ & 202 & 69.9 & 75 & 20.5 & 54 & 128.9 \\
\hline $58-7$ & 153 & 117.1 & 116 & 29.6 & 0 & 256.2 \\
\hline $58-8 \ldots$ & 180 & 90.3 & 100 & 23.7 & 100 & 233.5 \\
\hline
\end{tabular}

TABLE 4

MINERAL CONTENT OF THE ABOVEGROUND PORTION OF PLANTS, EXPRESSED AS PER CENT OF DRY WEIGHT ON DATE OF FIRST HARVEST, AND CALCULATED POUNDS PER ACRE REMOVED BY THE ABOVEGROUND PORTION OF THE CROP

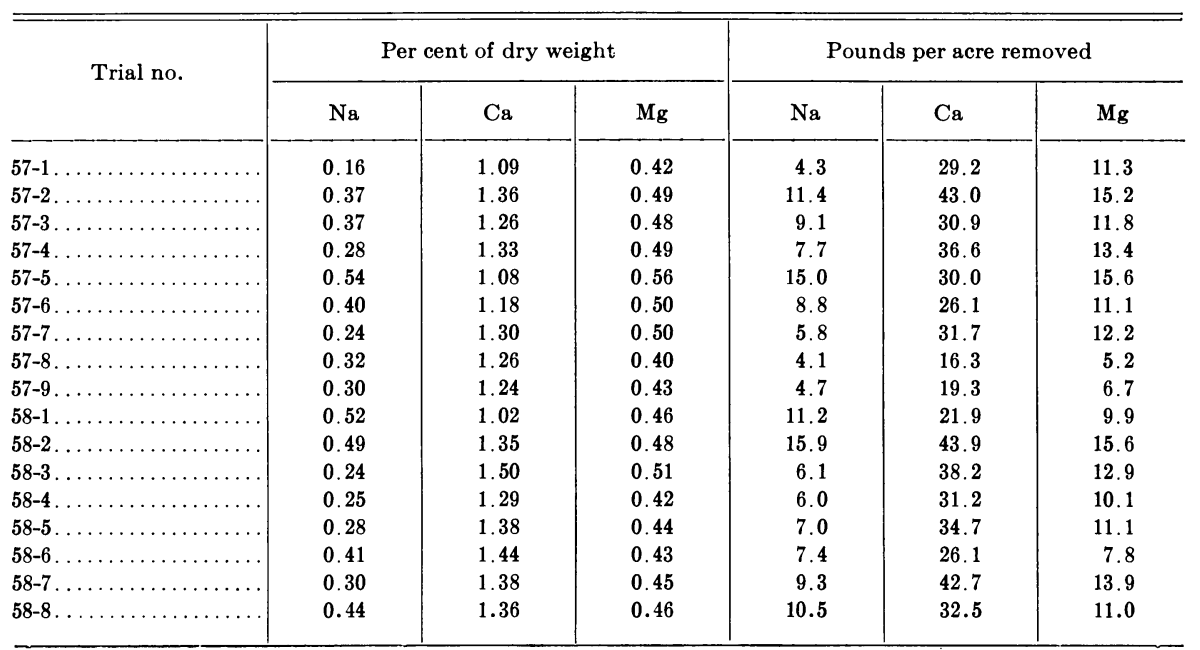


TABLE 5

AMOUNT PER ACRE OF MINERALS IN THE ROOT SYSTEMS ON THE DATE OF FIRST HARVEST

\begin{tabular}{|c|c|c|c|c|c|c|}
\hline \multirow{2}{*}{ Trial no. } & \multicolumn{6}{|c|}{ Pounds per acre of nutrients removed by the roots } \\
\hline & $\mathrm{N}$ & $\mathrm{P}_{2} \mathrm{O}_{5}$ & $\mathrm{~K}_{2} \mathrm{O}$ & $\mathrm{Na}$ & $\mathrm{Ca}$ & $\mathbf{M g}$ \\
\hline $57-9$ & 2.02 & 1.20 & 4.89 & 0.39 & 0.42 & 0.15 \\
\hline $58-2$ & 2.63 & 1.16 & 7.67 & 0.76 & 0.57 & 0.28 \\
\hline $58-6 \ldots$ & 2.32 & 1.13 & 6.68 & 0.87 & 0.80 & 0.23 \\
\hline
\end{tabular}

\section{TRIAL DATA-1957-1958}

TABLE 6

TRIAL 57-1-LOS COCHES RANCH, SOLEDAD

Planting date: January 16, 1957

First harvest: April 29

Soil type: Salinas very fine sandy loam

Growth period: 103 days Last harvest: May 7 $\mathrm{pH}: 7.9$

\begin{tabular}{|c|c|c|c|c|c|c|}
\hline \multirow{2}{*}{\multicolumn{3}{|c|}{ Date of application }} & \multirow{2}{*}{$\begin{array}{l}\text { Fertilizer } \\
\text { materials }\end{array}$} & \multicolumn{3}{|c|}{ Pounds of nutrients per acre } \\
\hline & & & & $\mathrm{N}$ & $\mathrm{P}_{2} \mathrm{O}_{5}$ & $\mathrm{~K}_{2} \mathrm{O}$ \\
\hline & & & & 178 & 108 & 0 \\
\hline February $25 \ldots \ldots \ldots$ & 0.5 & 5.7 & 0.91 & 6.65 & 0.79 & 6.10 \\
\hline March $4 \ldots \ldots \ldots \ldots$ & 0.9 & 10.4 & $\ldots$ & $\ldots$ & $\ldots$ & $\ldots$ \\
\hline March $12 \ldots \ldots \ldots \ldots$ & 6.7 & 9.9 & $\ldots$ & 4.28 & 0.45 & 6.44 \\
\hline $\operatorname{March} 18 \ldots \ldots \ldots \ldots$ & 8.1 & 11.7 & $\ldots$ & 4.58 & 0.46 & 5.10 \\
\hline $\operatorname{March} 25 \ldots \ldots \ldots \ldots$ & 26.9 & 10.8 & 0.47 & 4.50 & 0.52 & 5.34 \\
\hline April $1 \ldots \ldots \ldots \ldots$ & 55.3 & 9.2 & 0.50 & 4.49 & 0.50 & 6.44 \\
\hline April $8 \ldots$ & 127.3 & 8.7 & 0.59 & 4.15 & 0.42 & 6.44 \\
\hline April 15. . & 228.6 & 9.4 & 0.59 & 3.96 & 0.39 & 6.44 \\
\hline April 22... & 468.4 & 7.0 & 0.50 & 3.65 & 0.42 & 5.34 \\
\hline
\end{tabular}


TABLE 7

TRIAL 57-2-LOS COCHES RANCH, SOLEDAD

Planting date: April 22, 1957

First harvest: June 28

Soil type: Metz silty clay loam
Growth period: 67 days Last harvest: July 10 $\mathrm{pH}: 7.5$

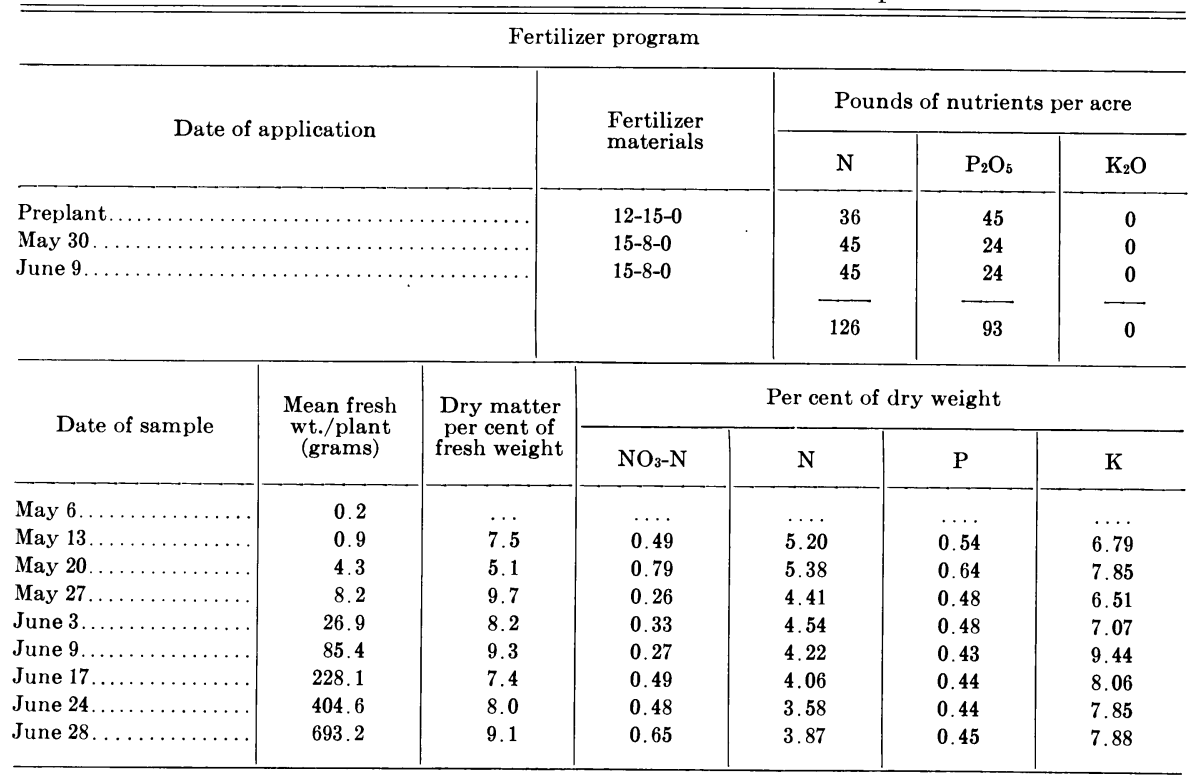

TABLE 8

TRIAL 57-3-SALACCI (BLANCO) RANCH, SALINAS

Planting date: April 22, 1957

First harvest: June 29

Soil type: Metz very fine sandy loam

Growth period: 68 days Last harvest: July 12 $\mathrm{pH}: 7.2$

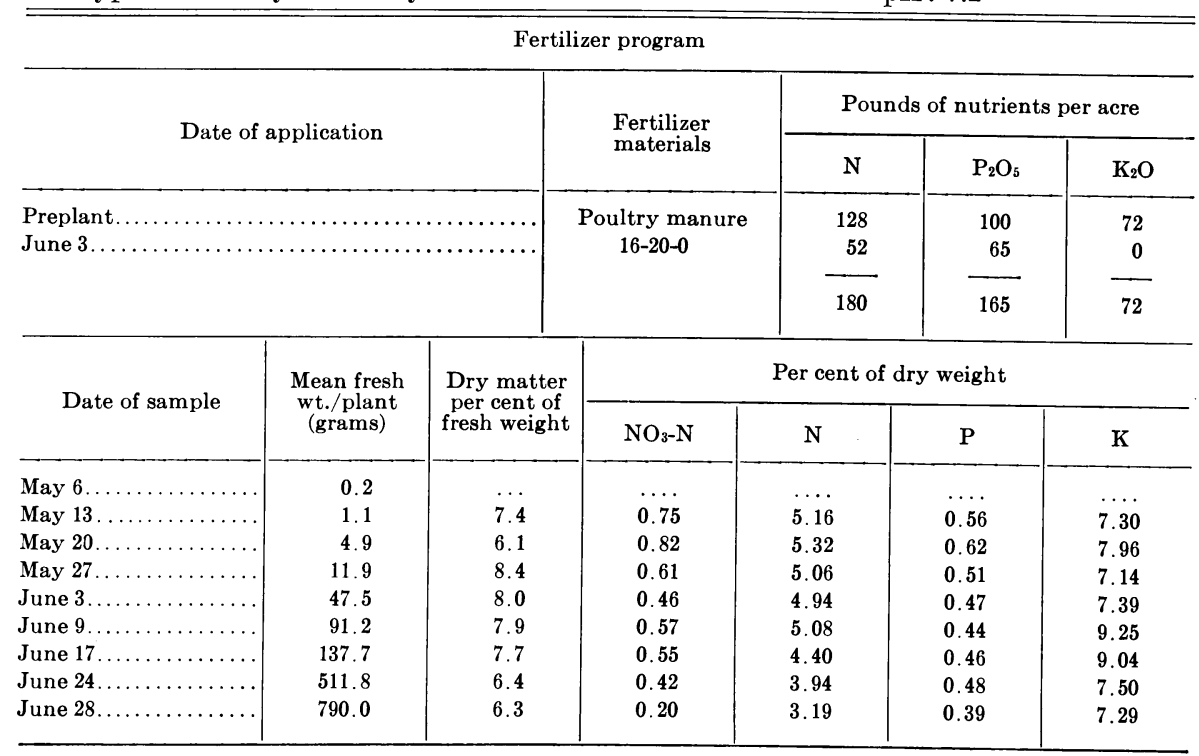


TABle 9

TRIAL 57-4-SALACCI (BLANCO) RANCH, SALINAS

Planting date: June 3, 1957

First harvest: August 14

Growth period: 72 days

Last harvest: August 19

Soil type: Salinas silty clay loam

$\mathrm{pH}: 6.5$

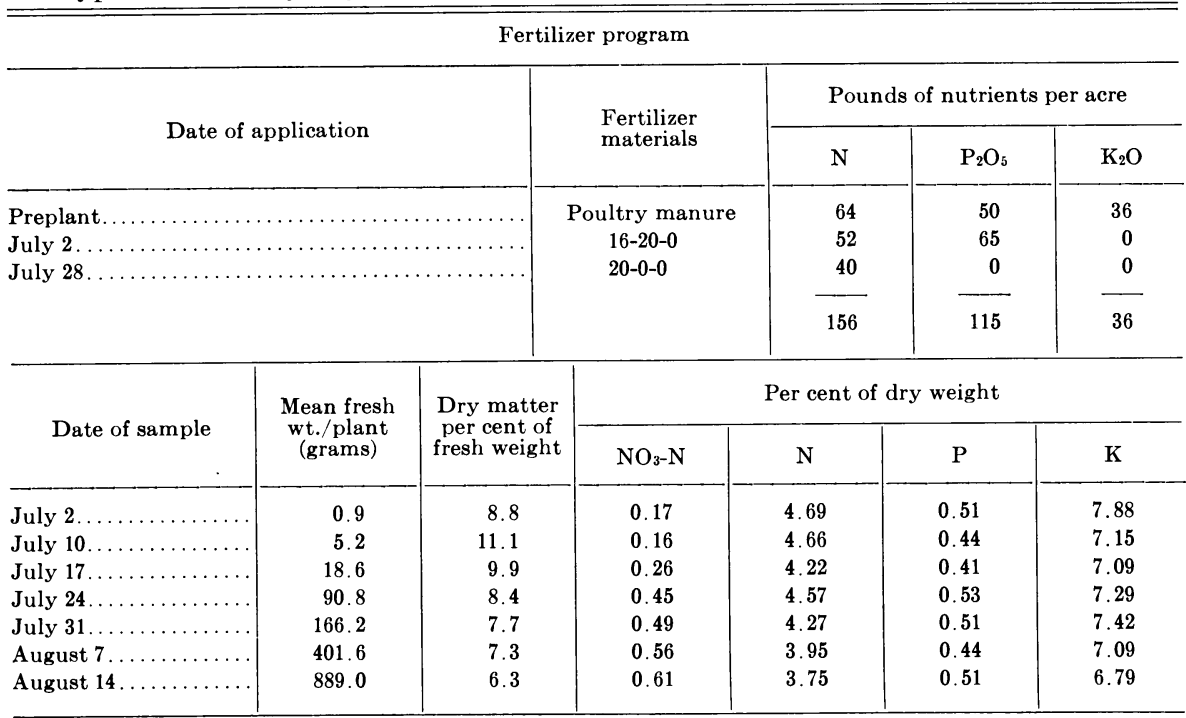

TABLE 10

TRIAL 57-5-CALLAGHAN RANCH, GONZALES

Planting date: July 17,1957

First harvest: September 24

Growth period: 69 days

Soil type: Chualar loam

Last harvest: September 24 $\mathrm{pH}: 7.2$

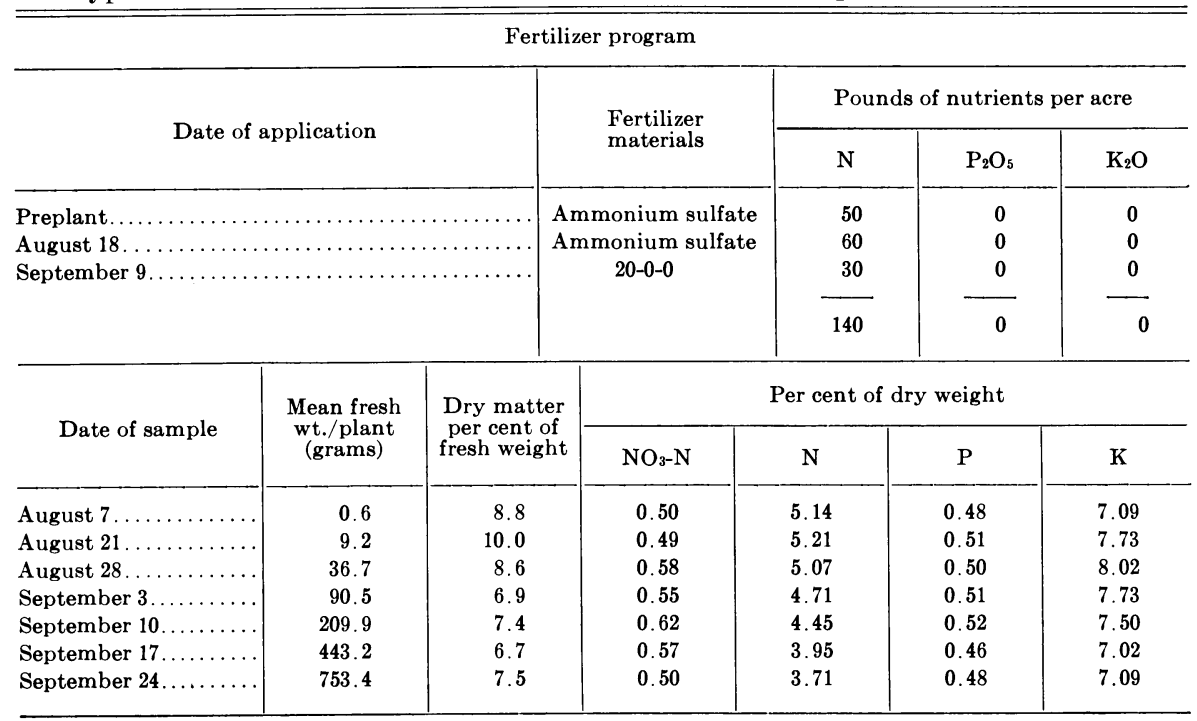


TABLE 11

TRIAL 57-6-CONLEY RANCH, SALINAS

Planting date: July 17, 1957

Growth period: 69 days

First harvest: September 24

Last harvest: September 30

Soil type: Salinas silty clay loam $\mathrm{pH}: 6.7$

\begin{tabular}{|c|c|c|c|c|c|c|}
\hline \multicolumn{7}{|c|}{ Fertilizer program } \\
\hline \multirow{2}{*}{\multicolumn{3}{|c|}{ Date of application }} & \multirow{2}{*}{$\begin{array}{l}\text { Fertilizer } \\
\text { materials }\end{array}$} & \multicolumn{3}{|c|}{ Pounds of nutrients per acre } \\
\hline & & & & $\mathrm{N}$ & $\mathrm{P}_{2} \mathrm{O}_{5}$ & $\mathrm{~K}_{2} \mathrm{O}$ \\
\hline \multicolumn{3}{|c|}{ 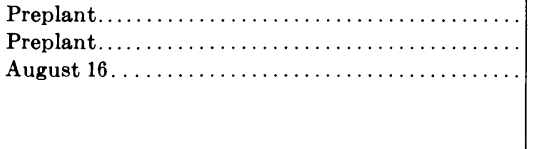 } & $\begin{array}{l}\text { Poultry manure } \\
\qquad \begin{array}{l}16-20-0 \\
36-0-0\end{array}\end{array}$ & $\begin{array}{r}128 \\
64 \\
108 \\
300\end{array}$ & $\begin{array}{r}100 \\
80 \\
0 \\
180\end{array}$ & $\begin{array}{r}72 \\
0 \\
0 \\
72\end{array}$ \\
\hline August $7 \ldots \ldots \ldots$ & 0.8 & 7.7 & 0.43 & 5.17 & 0.51 & 7.58 \\
\hline August $21 \ldots \ldots \ldots$ & 6.4 & 8.9 & 0.45 & 5. 23 & 0.53 & 8.10 \\
\hline August $28 \ldots \ldots$ & 60.9 & 8.4 & 0.59 & 4.91 & 0.51 & 7.58 \\
\hline September $3 \ldots$. & 141.8 & 7.1 & 0.59 & 4.78 & 0.53 & 7.50 \\
\hline September $10 \ldots$ & 273.4 & 7.2 & 0.50 & 4.25 & 0.48 & 6.83 \\
\hline September $17 \ldots$ & 400.6 & 6.9 & 0.51 & 3.86 & 0.45 & 6.30 \\
\hline September $24 \ldots \ldots$ & 808.2 & 5.6 & 0.49 & 3.32 & 0.45 & 6.04 \\
\hline
\end{tabular}

TABLE 12

TRIAL 57-7-LOS COCHES RANCH, SOLEDAD

Planting date: August 5, 1957

First harvest: October 21

Soil type: Salinas fine sandy loam
Growth period: 78 days

Last harvest: October 29 $\mathrm{pH}: 7.9$

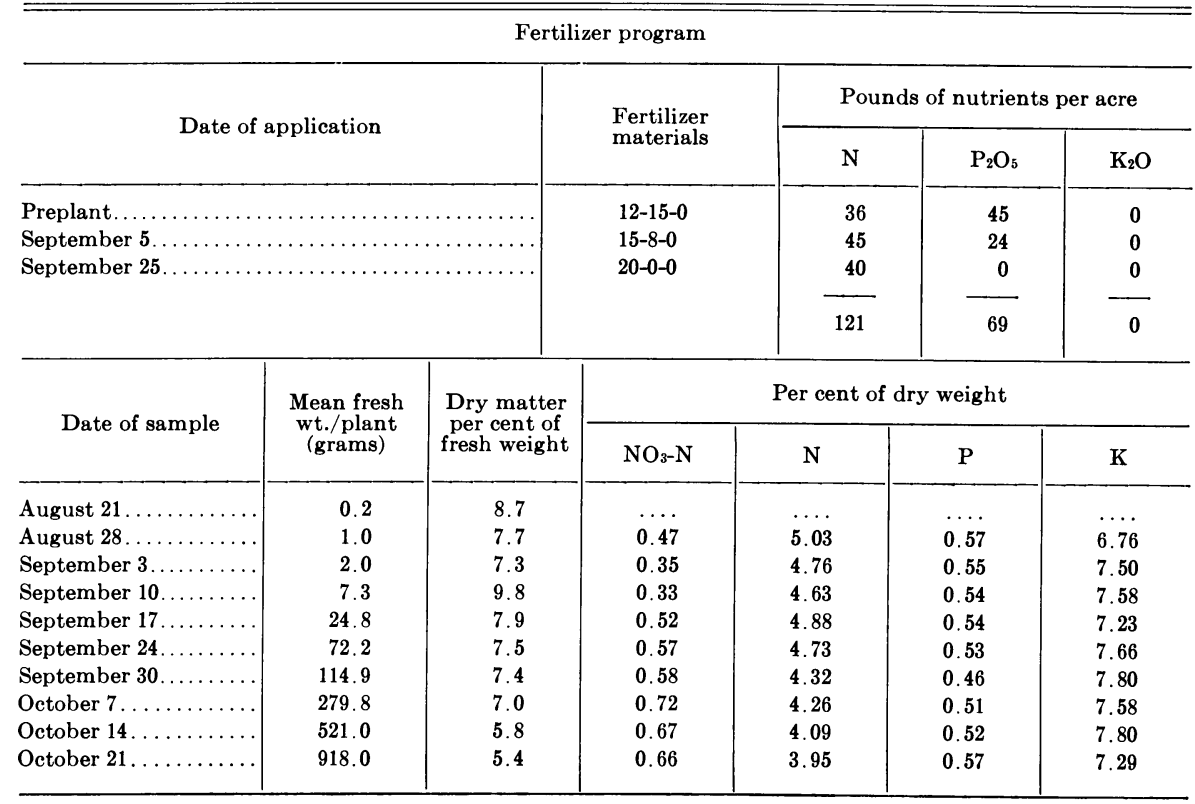


TABLE 13

TRIAL 57-8-HANSEN RANCH, SALINAS

Planting date: November 20, 1957

First harvest: April 14

Soil type: Greenfield coarse sandy loam
Growth period: 145 days Last harvest: April 14 $\mathrm{pH}: 7.4$

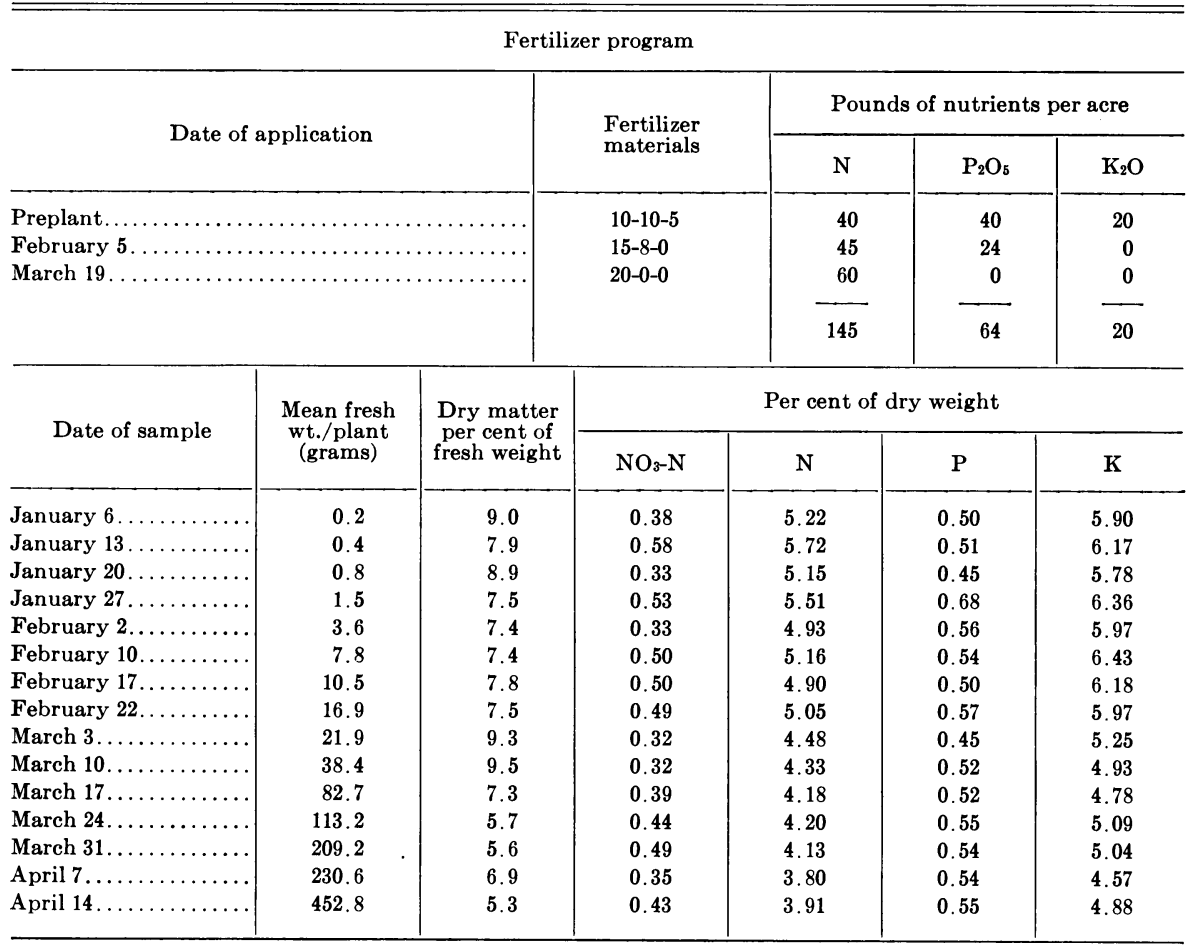


TABLE 14

TRIAL 57-9-DOUD RANCH, GONZALES

Planting date: December 14, 1957

First harvest: April 21

Soil type: Chualar loam
Growth period: 128 days Last harvest: April 30 $\mathrm{pH}: 6.8$

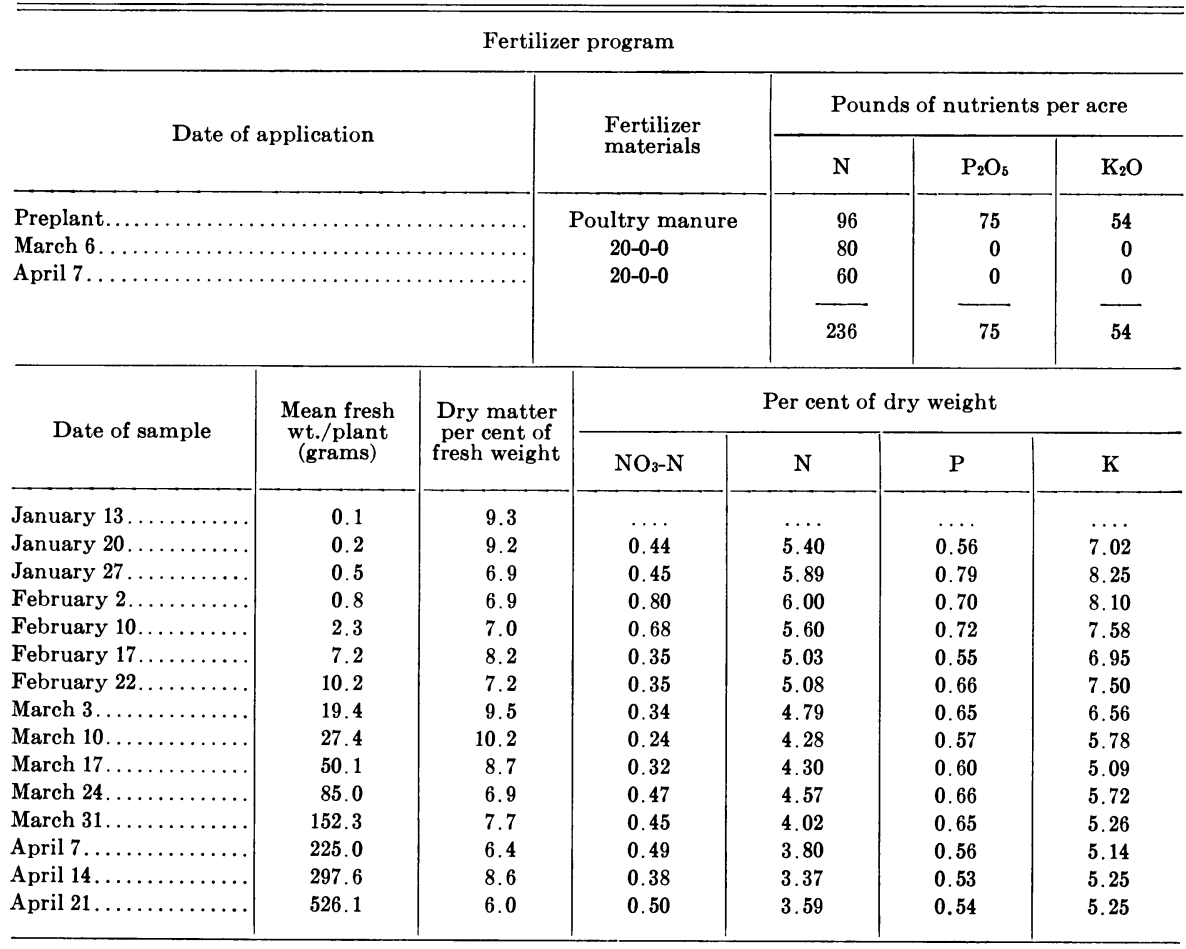


TRIAL 58-1-DOUD RANCH, GONZALES

Planting date: December 29, 1957

First harvest: April 30

Soil type: Salinas silty clay loam
Growth period: 120 days Last harvest: May 9 $\mathrm{pH}: 7.2$

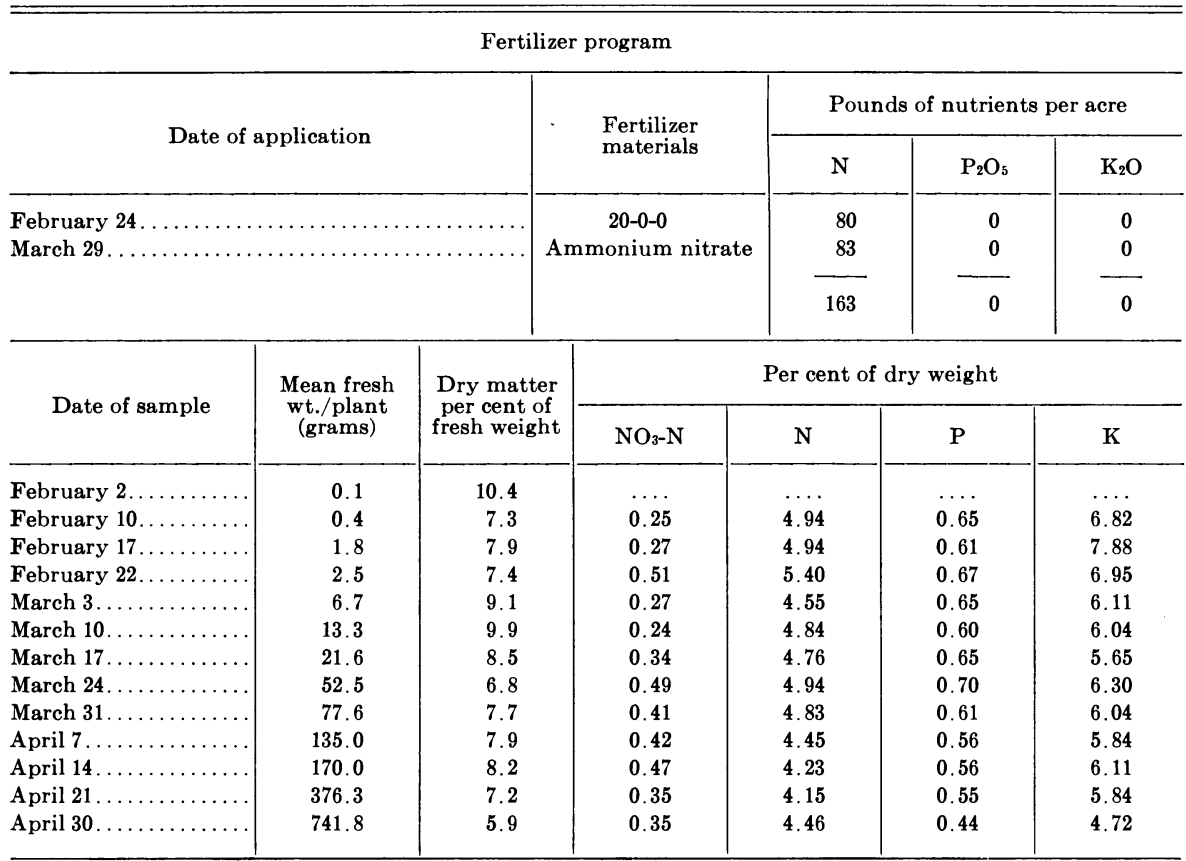


TABLE 16

TRIAL 58-2-DOUD RANCH, GONZALES

Planting date: February 6, 1958

First harvest: May 26

Soil type: Salinas fine sandy loam
Growth period: 109 days Last harvest: June 3 $\mathrm{pH}: 7.5$

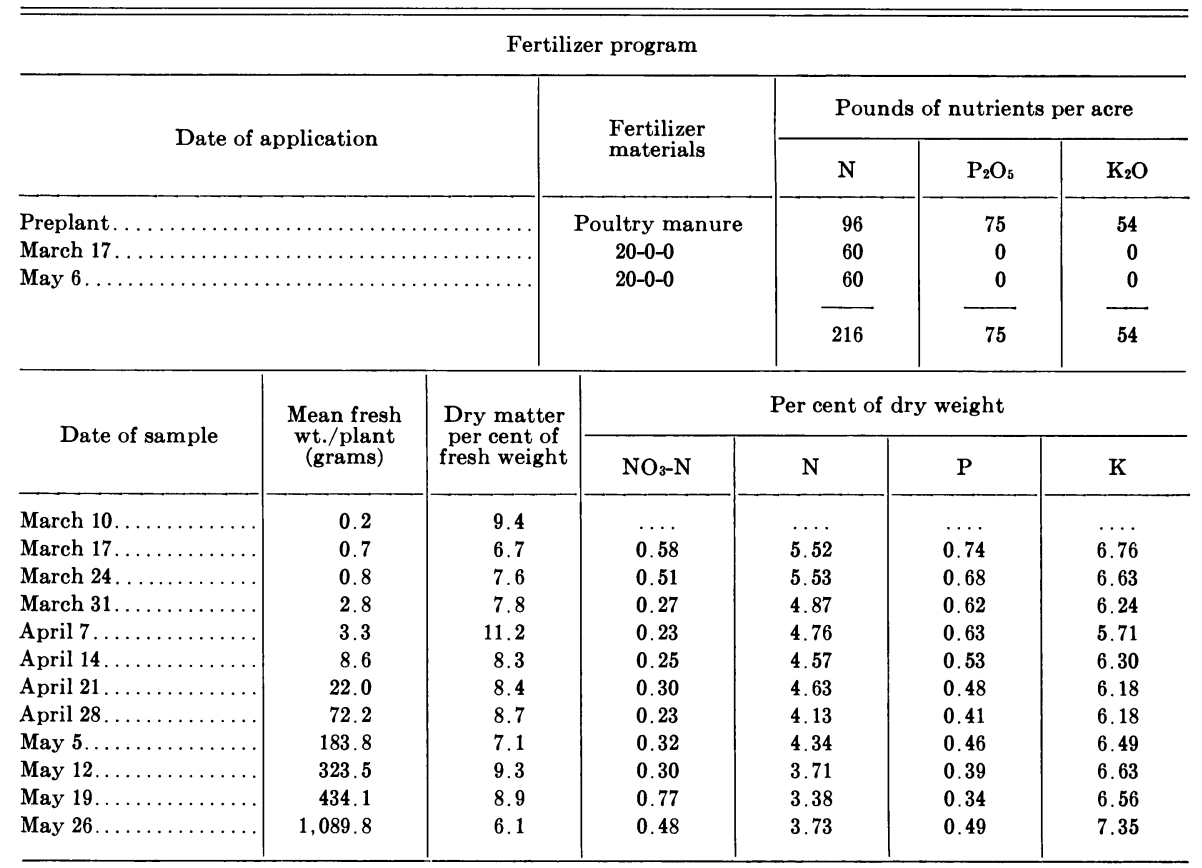


TRIAL 58-3-LOS COCHES RANCH, SOLEDAD

Planting date: February 16, 1958

First harvest: May 26

Soil type: Salinas fine sandy loam
Growth period: 100 days Last harvest: June 6 $\mathrm{pH}: 7.6$

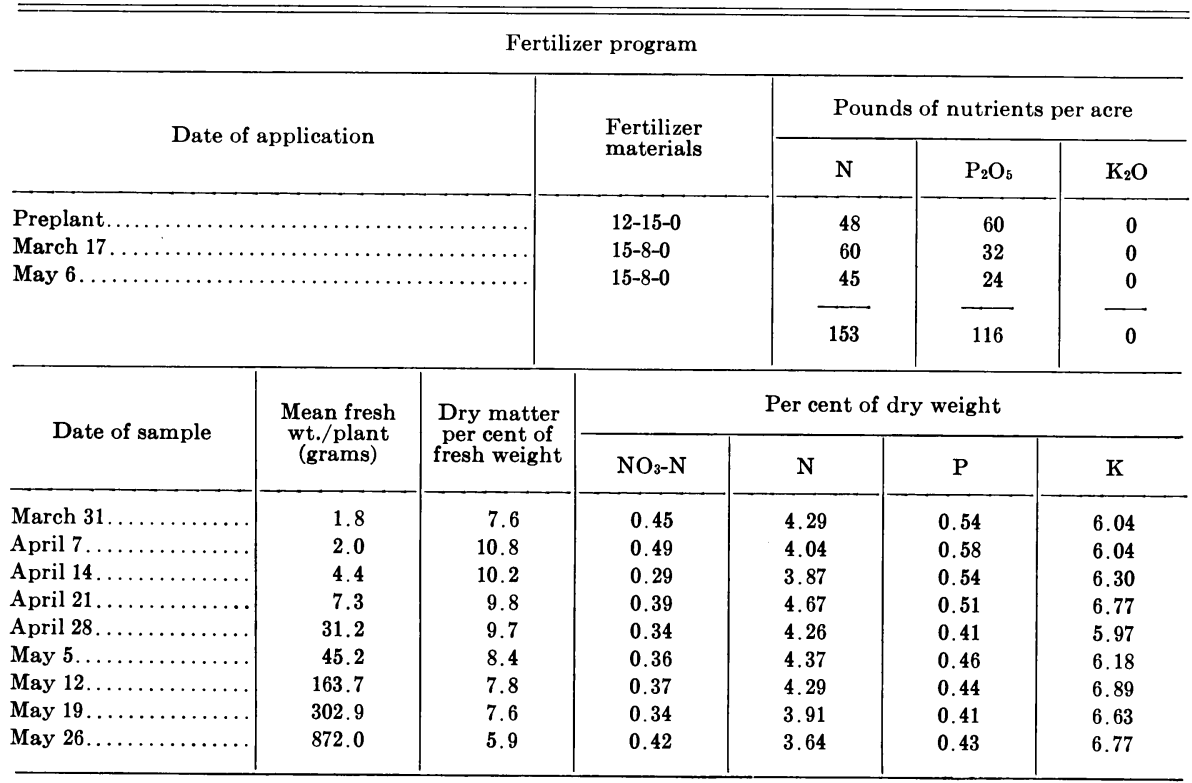


TABLE 18

TRIAL 58-4-LOS COCHES RANCH, SOLEDAD

Planting date: March 10, 1958

First harvest: June 9

Soil type: Salinas fine sandy loam
Growth period: 91 days Last harvest: June 11 $\mathrm{pH}: \mathbf{7 . 7}$

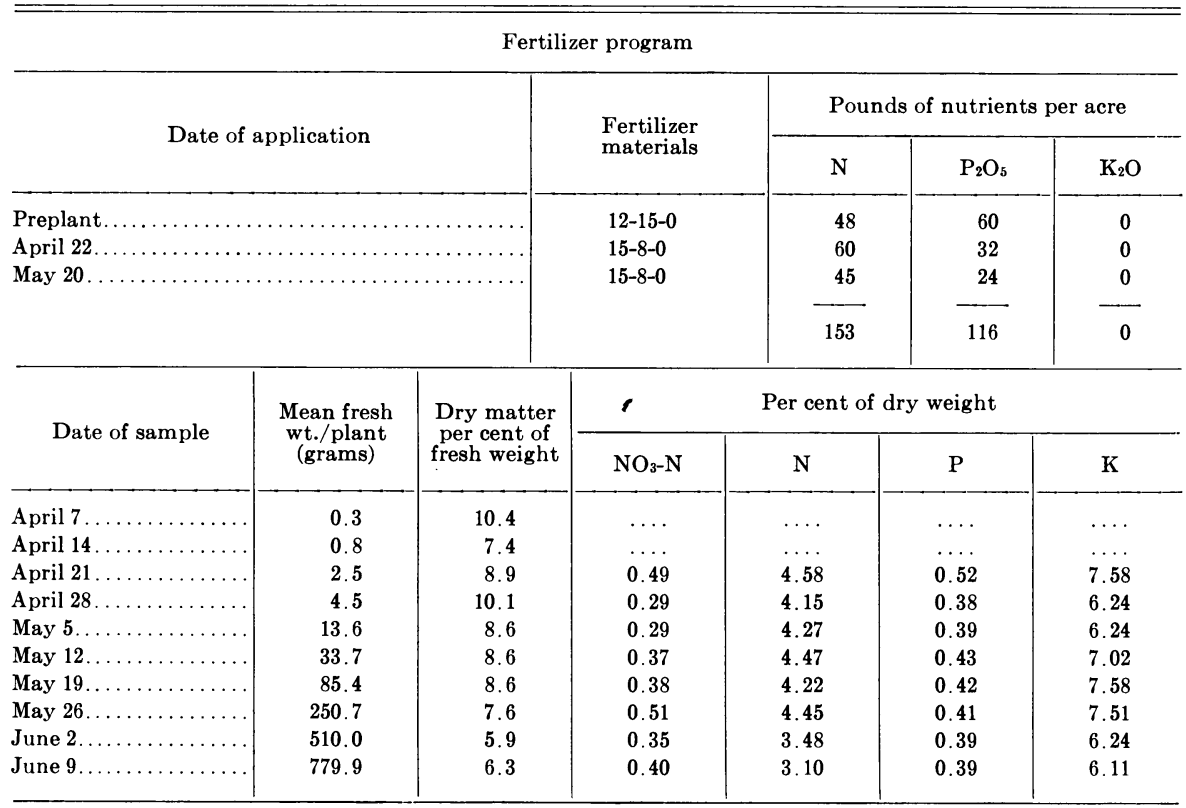


TRIAL 58-5-LOS COCHES RANCH, SOLEDAD

Planting date: April 11, 1958

First harvest: June 16

Soil type: Salinas silty clay loam
Growth period: 66 days

Last harvest: June 26 $\mathrm{pH}: \mathbf{7 . 6}$

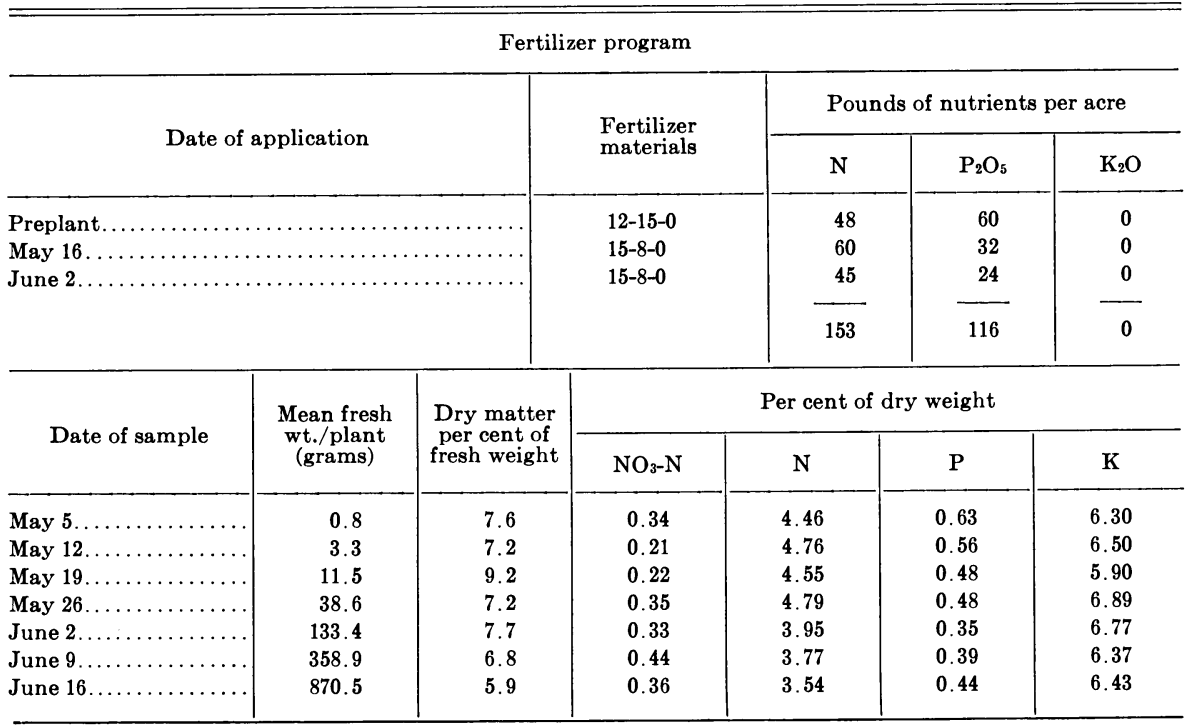

TABLE 20

TRIAL 58-6-WASSON RANCH, SALINAS

Planting date: May 16, 1958

First harvest: July 16

Soil type: Salinas fine sandy loam
Growth period: 61 days Last harvest: July 16 $\mathrm{pH}: 7.4$

Fertilizer program

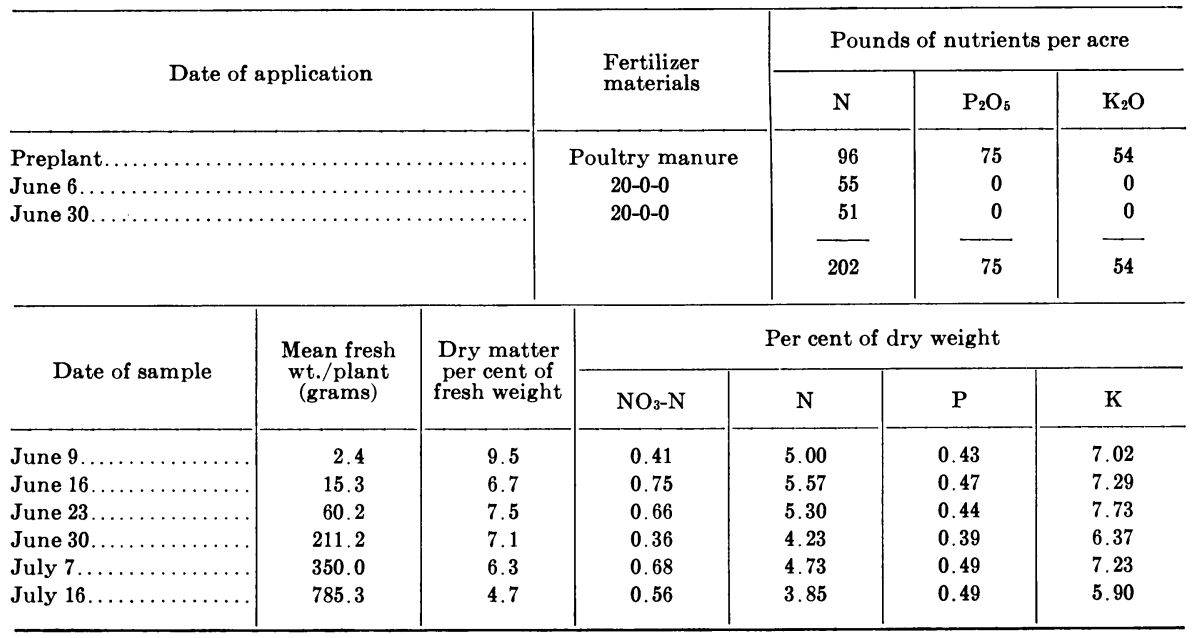


TABLE 21

TRIAL 58-7-LOS COCHES RANCH, SOLEDAD

Planting date: May 16, 1958

First harvest: July 21

Soil type: Metz silty clay loam

Growth period: 66 days

Last harvest: July 30

$\mathrm{pH}: 7.8$

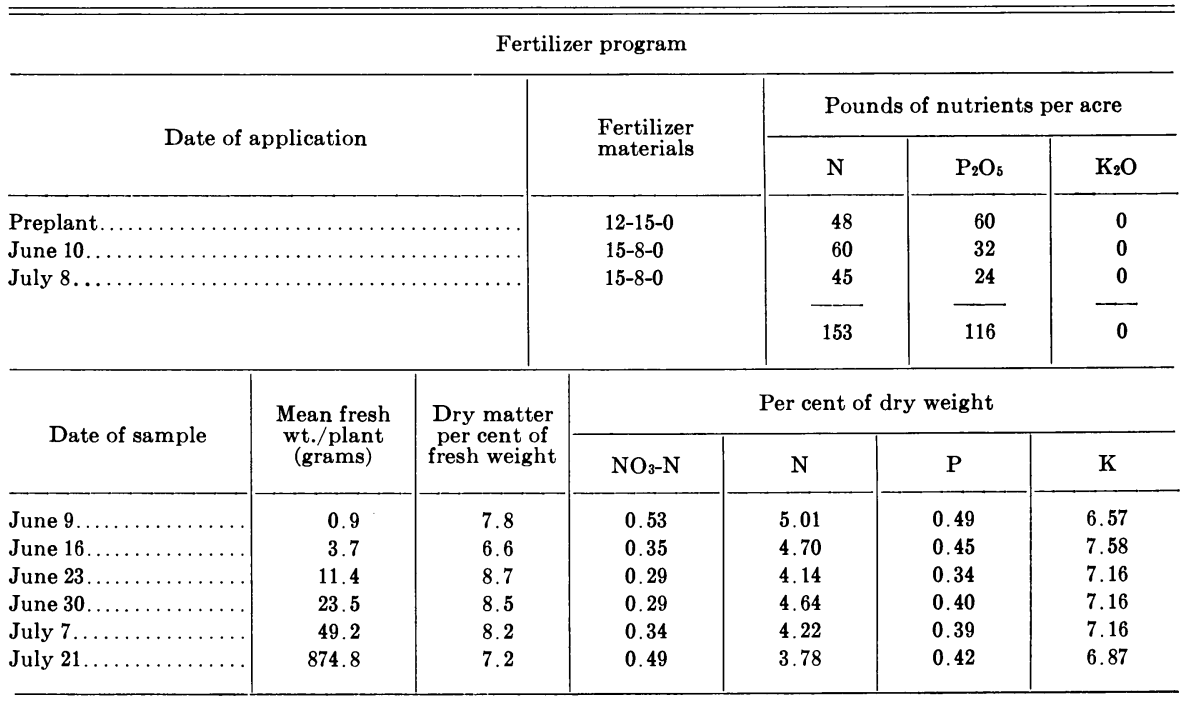

TABLE 22

TRIAL 58-8-LOS COCHES RANCH, SOLEDAD

Planting date: July 21, 1958

First harvest: September 29

Growth period: 70 days

Soil type: Salinas silty clay loam

Last harvest: October 8

$\mathrm{pH}: 7.8$

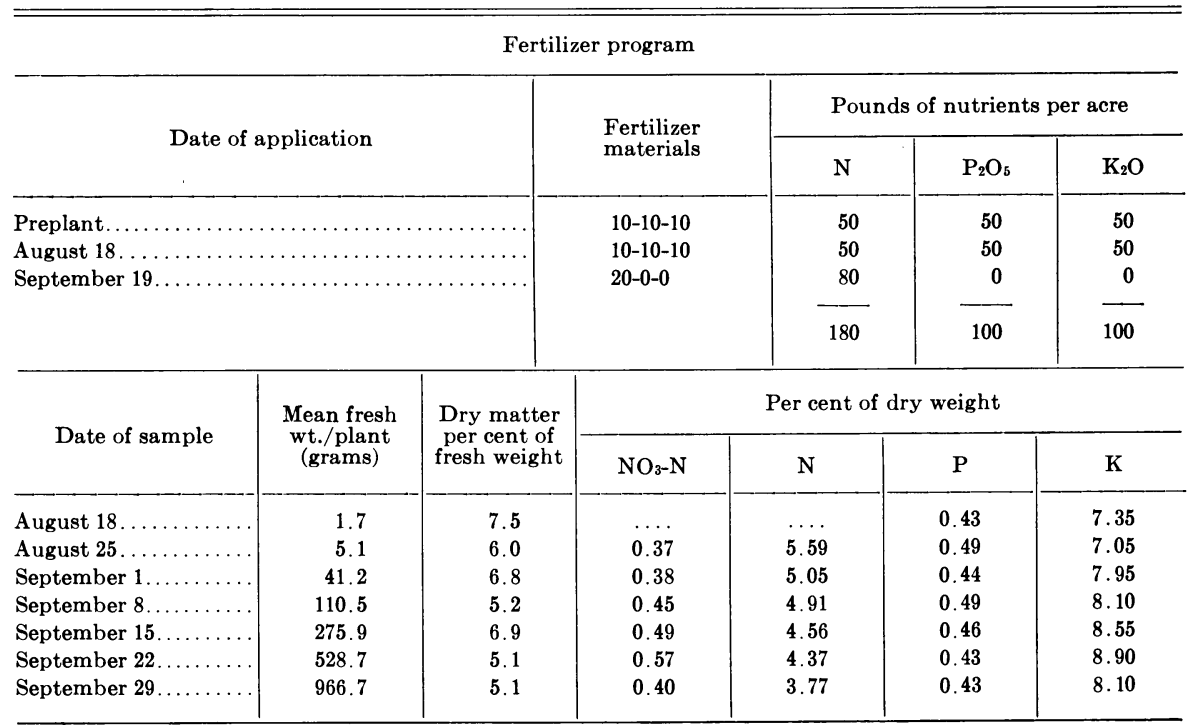




\section{LITERATURE CITED}

BoHN, G. W., and T. W. WhitakeR

1951. Recently introduced varieties of head lettuce and methods used in their development. U.S.D.A. Circ. $881: 1-27$.

Dean, G. W., and C. O. McCorkLe, JR.

1960. Trends for major California crops. Calif. Agr. Expt. Sta. Circ. 488:54-59.

Fujimura, T., T. Mori, T. Kitano, and Y. Aoki

1960. Studies on fertilization for lettuce. I. Nutrient absorption at different stages of growth and effect of nitrogen and potassium on growth. Jour. Hort. Assoc. Japan $29: 191-96$.

Hoos, S., and H. F. PHELPS

1948. Commercial head lettuce economic status, 1947. Calif. Agr. Expt. Sta. Cire. $378: 1-18$.

HoRowITz, W. (Ed.)

1955. Methods of analysis of the Association of Official Agricultural Chemists. Association of Official Agricultural Chemists, Washington 4, D.C. 1008 pages.

KnotT, J. E., and A. A. TAVERnetTi

1944. Production of head lettuce in California. Calif. Agr. Expt. Sta. Circ. 128:1-51.

LORENZ, O. A., and P. A. Minges

1942. Nutrient absorption by a summer crop of lettuce in Salinas Valley, California. Proc. Amer. Soc. Hort. Sci. 40:523-27.

LORENZ, O. A., F. W. ZiNK, and F. D. HowARD

1956. Nutrient survey of lettuce in Salinas Valley, 1954. Univ. Calif. Dept. Veg. Crops Series 87.15 pages.

MAdARIAGA, F. J., and J. E. KNotT

1951. Temperature summations in relation to lettuce growth. Proc. Amer. Soc. Hort. Sci. $58: 147-52$.

McGeorge, W. T., M. F. Wharton, and W. A. Frazier

1940. Fertilization of lettuce on alkaline-calcareous soils : soil and plant studies. Arizona Agr. Expt. Sta. Tech. Bul. $85: 399-451$.

Veihmeyer, F. J., and A. H. Holland

1949. Irrigation and cultivation of lettuce. Calif. Agr. Expt. Sta. Bul. 711:1-51.

WENT, F. W.

1950. The response of plants to climate. Science 112:489-94.

Yamaguchi, M., and P. A. Minges

1956. Brown checking of celery, a symptom of boron deficiency. I. Field observations, variety susceptibility, and chemical analyses. Proc. Amer. Soc. Hort. Sci. 68: 318-28.

ZINK, F. W., and R. G. GROGAN

1954. The interrelated effect of "big vein" and market price on the yield of head lettuce. Plant Disease Reptr. $38: 844-46$.

Zink, F. W., and K. A. Kimble

1960. Effect of time of infection by lettuce mosaic virus on rate of growth and yield in Great Lakes lettuce. Proc. Amer. Soc. Hort. Sci. 75:448-54.

ZINK, F. W., and J. E. WELCH

1954. Performance of commercial head lettuce varieties and strains in the central coastal section of California in 1953. Univ. Calif. Dept. Veg. Crops Series 62. 27 pages. 
The journal Hilgardia is published at irregular intervals, in volumes of about 600 pages. The number of issues per volume varies.

Subscriptions are not sold. The periodical is sent as published only to libraries, or to institutions in foreign countries having publications to offer in exchange.

You may obtain a single copy of any issue free, as long as the supply lasts; please request by volume and issue number from:
Agricultural Publications
Room 207 University Hall
2200 University Avenue
Berkeley 4, California

The limit to nonresidents of California is 10 separate issues on a single order. A list of the issues still available will be sent on request.

In order that the information in our publications may be more intelligible it is sometimes necessary to use trade names of products or equipment rather than complicated descriptive or chemical identifications. In so doing it is unavoidable in some cases that similar products which are on the market under other trade names may not be cited. No endorsement of named products is intended nor is criticism implied of similar products which are not mentioned. 